\title{
Alternative matrices in forensic toxicology: a critical review
}

\author{
Eduardo Geraldo de Campos ${ }^{1}$ - Bruno Ruiz Brandão da Costa ${ }^{1} \cdot$ Fabiana Spineti dos Santos ${ }^{2} \cdot$ Fernanda Monedeiro $^{2}$. \\ Marcela Nogueira Rabelo Alves ${ }^{3}$. Wilson José Ramos Santos Junior ${ }^{1} \cdot$ Bruno Spinosa De Martinis $^{2}$ (1)
}

Received: 6 May 2021 / Accepted: 19 June 2021 / Published online: 19 August 2021

(c) The Author(s) 2021

\begin{abstract}
Purpose The use of alternative matrices in toxicological analyses has been on the rise in clinical and forensic settings. Specimens alternative to blood and urine are useful in providing additional information regarding drug exposure and analytical benefits. The goal of this paper is to present a critical review on the most recent literature regarding the application of six common alternative matrices, i.e., oral fluid, hair, sweat, meconium, breast milk and vitreous humor in forensic toxicology. Methods The recent literature have been searched and reviewed for the characteristics, advantages and limitations of oral fluid, hair, sweat, meconium, breast milk and vitreous humor and its applications in the analysis of traditional drugs of abuse and novel psychoactive substances (NPS).

Results This paper outlines the properties of six biological matrices that have been used in forensic analyses, as alternatives to whole blood and urine specimens. Each of this matrix has benefits in regards to sampling, extraction, detection window, typical drug levels and other aspects. However, theses matrices have also limitations such as limited incorporation of drugs (according to physical-chemical properties), impossibility to correlate the concentrations for effects, low levels of xenobiotics and ultimately the need for more sensitive analysis. For more traditional drugs of abuse (e.g., cocaine and amphetamines), there are already data available on the detection in alternative matrices. However, data on the determination of emerging drugs such as the NPS in alternative biological matrices are more limited.

Conclusions Alternative biological fluids are important specimens in forensic toxicology. These matrices have been increasingly reported over the years, and this dynamic will probably continue in the future, especially considering their inherent advantages and the possibility to be used when blood or urine are unavailable. However, one should be aware that these matrices have limitations and particular properties, and the findings obtained from the analysis of these specimens may vary according to the type of matrix. As a potential perspective in forensic toxicology, the topic of alternative matrices will be continuously explored, especially emphasizing NPS.
\end{abstract}

Keywords Alternative matrices $\cdot$ Sweat $\cdot$ Meconium $\cdot$ Breast milk $\cdot$ Newly emerging alternative matrices $\cdot$ NPS

Bruno Spinosa De Martinis

martinis@usp.br

1 Faculdade de Ciências Farmacêuticas de Ribeirão Preto, Universidade de São Paulo, Av. do Café s/n, Monte Alegre, Ribeirão Preto, São Paulo 14040-903, Brazil

2 Faculdade de Filosofia, Ciências e Letras de Ribeirão Preto, Universidade de São Paulo, Av. Bandeirantes 3900, Ribeirão Preto, São Paulo 14040-901, Brazil

3 Instituto Master de Ensino Presidente Antônio Carlos - IMEPAC ARAGUARI, Av. Minas Gerais 1889, Araguari, MG 38444-128, Brazil

\section{Introduction}

One of the goals of forensic toxicology is to apply approaches of analytical chemistry, toxicology and pharmacology for investigating compounds of forensic interest in samples collected in casework including death investigations, driving under the influence of substances, doping control, drug-facilitated crimes and more. For this reason, it is of paramount importance to investigate the presence of a given drug in biological fluids collected from the individual in a suspected-intoxication case, since this would be important evidence of drug intake. Drug testing in forensic toxicology has been historically and traditionally performed in whole blood, plasma, serum and urine specimens, which 
are considered conventional or traditional biological fluids $[1,2]$. Since many years ago, alternative biological matrices have been explored in toxicological testing, especially due to their advantages over conventional matrices [2-4]. In general, these advantages include easier and less invasive specimen collection and in some cases, larger detection windows [3]. In addition, these matrices can be used when blood specimens are not available, degraded, potentially affected by postmortem redistribution or delayed collection after drug intake [5]. However, due to inherent characteristics and toxicokinetics, drug levels in some of these matrices may be reduced in comparison to blood or urine. For this reason, modern advancements in instrument's technology have made possible the exploration and analysis of alternative matrices; modern and sensitive instruments are enabling the detection of lower concentrations of drugs and poisons in some of these alternative specimens [1]. Some of these samples such as oral fluid and hair are already well established and have been implemented in drug testing by several laboratories.

The goal of this paper is to discuss common alternative matrices, i.e., oral fluid, hair, sweat, meconium, breast milk and vitreous humor, considering their properties, advantages and limitations in drug testing. In addition, some of the recent studies based on the application of these matrices in the analysis of classic drugs and novel psychoactive substances (NPS) will be reviewed. Other less frequently reported biological specimens are also briefly discussed.

\section{Oral fluid}

Oral fluid is an exocrine secretion produced mainly by the three pairs of major salivary glands (parotis, submandibularis and sublingualis) at a rate of $0.5-1.5 \mathrm{~L}$ per day $[6,7]$. It consists mainly of water (approximately 99\%), proteins, epithelial cells, bacteria, food debris and traces of drugs, composition that differs the oral fluid from the saliva [7-9].

The oral fluid is considered a direct filtering of blood because the salivary glands are highly perfused with blood [10]. The main mechanisms by which drugs pass from blood into the oral fluid are the passive diffusion (hydrophobic compounds) and ultrafiltration (low molecular hydrophilic substances) [11]. Drugs are usually present in their free fraction form since the bounded drug may not infiltrate through the salivary tissues [9]. Additionally, because oral fluid is slightly acidic relative to blood ( $\mathrm{pH} 5.8-6.8)$, weak basic drugs tends to be ionized and, consequently, to be present in higher concentrations in this matrix (referred as ion trapping) $[12,13]$. It is important to mention that many psychoactive drugs have such a characteristic, including cocaine and amphetamines [13].

The interest in using oral fluid for forensic and toxicological purposes has grown significantly in the recent years due to the advantages of this matrix, and also due to the improvement in extraction and analysis procedures. In this sense, as compared to the conventional matrices, the collection of oral fluid is simpler, easier, safer (both for patients and collection staff), painless (noninvasive) and avoids privacy issues [14, 15]. For instance, blood sampling is invasive and requires a trained health professional, while urine collection in many cases demands supervision to avoid sample adulteration [16, 17]. Both issues are overcome when sampling oral fluid. In addition, this matrix is simpler, presenting less interference as compared to blood and urine; consequently, the drug analysis can be performed more accurately [14-16, 18, 19]. Finally, oral fluid is ideal for drug online monitoring, as the drug levels in this biological matrix are thought to reflect the free drug plasma concentration, which may also reflects the drug activity [9].

Regarding of disadvantages of this matrix, oral fluid composition is influenced by several factors, such as the circadian rhythm, healthy status, age, gender, therapeutics, diet, and smoking habits $[6,9,20]$. With this respect, the interpretation of the analysis of drugs that are inhaled or smoked (such as cocaine, nicotine and heroin) may be impaired due to oral cavity contamination [9]. Additionally, the oral fluid volume for testing is limited (about $1 \mathrm{~mL}$ ), and the analytes may be present in very low amounts, requiring very sensitive detection methods. However, the improvement in sample preparation methods (such as microextraction techniques), and the advances of analysis procedures (including gas chromatography coupled to mass spectrometry (GC-MS) or liquid chromatography coupled to mass spectrometry (LC-MS)) are efficient in reducing the impact of the last issues [8]. Finally, caution must be taken with the choice of the oral fluid sampling device, since it may directly influence the analytical result, and it is a very important variable when standardizing a method and when comparing the results of different laboratories [15]. For detailed description of the oral fluid collection devices, refer to [15, 20, 21].

For all the advantages over conventional matrices cited previously, the oral fluid is currently the most suitable alternative matrix for the assessment of recent exposure of psychoactive drugs [12]. One of the main applications is the oral fluid analysis of individuals suspected of driving under the influence of drugs, where this matrix is usually screened for cocaine, cannabinoids, amphetamines, benzodiazepines, opiates and ethanol [12, 22-26]. With this respect, oral fluid is a good alternative to breathalyzer assessment, because it provides simultaneous identification of alcohol and other psychoactive drugs, and also allows the sample to be stored and reanalyzed if there is a judicial request [16].

Another application of oral fluid is the on-site (real time) monitoring for doping purposes, as Bessonneau et al. [27] collected oral fluid to monitor in vivo 49 prohibited substances in sports, including psychoactive drugs, such as 
cannabidiol (CBD) and cannabinol (CBN), heroin, methadone, fentanyl, and strychnine. In addition, there are several studies that use this matrix for the analysis of drugs of abuse for clinical and forensic purposes, such as cannabinoids [28, 29], amphetamines [30, 31], cocaine [32, 33], opioids [34, 35], and benzodiazepines [36]. Finally, the analysis and identification of NPS is a hot topic in Forensic Toxicology, and oral fluid is one of the main matrices used for the assessment of these substances. With this regard, the recent studies are usually focused in analyze different classes of NPS using small volumes of oral fluid [37-39].

\section{Hair}

Hair is a filamentous structure constituted of keratin (65-95\%), water (15-35\%), lipids (1-9\%) and some minerals $(0.25-0.95 \%)$. The average hair growth rate is about $0.35 \mathrm{~mm}$ per day or $1-1.5 \mathrm{~cm}$ per month, depending on anatomical region, ethnic origin, gender and age. When the scalp hair is not sufficient or absent to perform an analysis, the hair can be collected from other anatomical regions, such as the pubis, arms, armpits or face (beard) [3].

Hair analysis can be used to determine the concentration of many licit or illicit drugs in their parent or metabolized form such as nicotine, the biomarker of tobacco exposure [40-42]; ethyl glucuronides (EtG) and total fatty acid ethyl esters (FAEEs), which are biomarkers of ethanol intake [43-46]; cannabis [47-50]; cocaine [51-54]; amphetamines [55-57]; and NPS, including phenethylamines, piperazines, synthetic cathinones and synthetic cannabinoids [58,59].

The accurate mechanisms involved in the incorporation of drugs into hair are still unclear. The most accepted model assumes that drugs and their metabolites are incorporated in hair by passive diffusion through blood capillaries to the cells of the growing matrix, at the base of the hair follicle. As the cells elongate and age, they die and coalesce, forming the hair fiber carrying the drug incorporated in the matrix. Other possible mechanisms are diffusion from sweat (sweat glands) or sebum to the hair as well as environmental contamination (smoke, dust or physical transfer from contaminated hands) [60].

The deposition of drugs in hair can be influenced by hair's melanin content (hair color) and ethnic origin; and lipophilicity, polarity and basicity of the parent drug or its metabolites. Generally, dark pigmented hair tends to bind to greater amounts of drug than less pigmented hair, because the analytes are believed to bind more efficiently to the melanin found in colored hair [61]. Melanin has a hydrophobic and acidic nature, which makes this pigment responsible for the affinity of hair to alkaline drugs such as cocaine, codeine and ketamine. Lipophilic and basic molecules are more incorporated than polar analytes $[60,62]$. Other parameters that can change the concentration of drugs in the hair are the difference of hair growth rate among various anatomic body sites, such as head, pubic, axillary, face and chest hair [63], the washing procedure used before hair analysis and the use of cosmetic and heat hair treatments. The products used for bleaching, perming, dyeing or relaxation contain strong bases, which may affect the stability or the amount of drug present in the hair matrix. These treatments, associated with continuous exposure to natural factors such as sunlight, weather and pollution can contribute to increase the damage in the hair cuticle [64]. In particular, photodegradation of drugs through the formation of free radicals or photosensitization reactions by intermolecular energy transfer can occur when the hair is exposed to sunlight or artificial light for many hours per day [65].

The advantages of hair analysis over other conventional biological samples are: easy and noninvasive collection (it does not require any specialized training neither violate individual's privacy); easy transportation and storage (a solid and durable structure assure long stability); negligible risk of infection; and assessment of retrospective and cumulative drug exposure from months to years (since drugs incorporating into hair have a large window of detection). Furthermore, it is possible to evaluate chronic drug use through segmental analysis, in which hair is cut into smaller pieces and analyzed separately [66-68], and also to locate and characterize drugs on a single hair sample, using matrixassisted laser desorption/ionization (MALDI) combined with imaging mass spectrometry $[69,70]$. In postmortem cases, when investigating the presence of drugs consumed by the deceased a long time after death, a hair sample might be the only biological matrix available for the analysis.

Hair testing also has some limitations. The detection of recent drug use (within 7 days) is not possible. Accurate and sensitive methods are necessary to detect very low drug concentrations and the cost of analysis is higher than that of other biological samples. Immunoassay tests alone do not provide reliable results and the use of a confirmatory technique such as GC-MS or LC-MS [62] is needed. Interpretation of analytical findings is more complex, considering the complexity and variability of the incorporation of the drugs into hair matrix [71]. There is no consensus on "the most accurate and sensitive" method for hair analysis (washing, extraction and identification steps), which can lead to misinterpretation of very low drug concentrations. Considering this issue, the Society for Hair Testing (SOHT) provides guidelines that regulate information about collection, testing, cut-offs and reporting of confirmed results [72].

Hair analysis is of great interest in forensic, clinical and analytical sciences and the most common applications in routine analysis include workplace drug testing, drug-facilitated crime, child custody, in utero drug exposure, monitoring abstinence to drugs and/or ethanol and others [71, 73]. 
Therefore, hair is an alternative biological sample of large importance in forensic toxicology that allows an evaluation of historic drug use/exposure, depending on the hair length.

\section{Sweat}

Sweat is the fluid produced by the eccrine and apocrine sweat glands. When sweat is generated on the surface of the epidermis, it evaporates slowly, fulfilling its role in the maintenance of body temperature. This fluid is mainly composed by water (around 99\%) and electrolytes, carbohydrates, amino acids, urea, lactate and other organic compounds. Sweat has low tonicity and a slightly acidic nature, displaying mean $\mathrm{pH}$ of 6.3. However, factors such as gender, age and physical exercise, may alter this value (which can range from 5.2 to 6.9). It is believed that the volume of sweat perspired daily by the whole body of an individual can amount to between 300 and $700 \mathrm{~mL}$, under normal environmental conditions [74-76]. Depending on how sweat sample is collected, it can also include secretions generated by the sebaceous glands. While hydrophilic composition represents the largest portion of this fluid, hydrophobic content may consist of less than $1 \%$ of sweat fraction, being mainly derived from sebum and apocrine secretion [77]. Within the organic portion of sweat, there are endogenous and exogenous substances excreted by the organism [78]. Mechanisms of transportation of substances, such as drugs, to sweat remain not fully elucidated. However, it is believed that the primary mechanism involved in the delivery of substances from bloodstream to sweat occurs through passive diffusion, from adjacent capillaries to the sweat glands. Substances could also reach skin's surface by migrating through skin layers (transdermal migration). Factors governing the excretion of substances into sweat are lipophilicity, molecular mass, protein binding and $\mathrm{pKa}$ of the molecule [79].

A series of advantages lead us to the use of sweat as biological matrix for the investigation of compounds of interest. Sweat collection is noninvasive and can be performed in simple and safe manner. In addition, samples present less complex composition, are easier to be handled and offer less risks of pathogen transmission. Additionally, sweat samples can represent a cumulative record of substances excreted by an individual within a given timeframe. This fluid occasionally provides a greater window of detection for the identification of substances in comparison to blood: xenobiotics can be detected in sweat up to 14 days after exposure [80]. Some of the disadvantages include the rather low concentration of analytes, demanding the use of more sensitive analytical techniques to enable proper determination of targets in this matrix. In addition, there is a lack of information regarding the possibility of environmental contamination and reabsorption of substances by skin [81]. Volume of collected sample is also dependent on both internal (inter- and intravariability in sweat production) and external factors (physical exercise, room temperature, etc.) [79].

Sweat can be collected by wiping the skin with gauze, cotton, filter paper or plastic materials [82]. For specialized collection of sweat there are proper devices available commercially, named PharmChek ${ }^{\circledR}$ patches (PharmChem, Inc, Fort Worth, TX, USA). Basically, these devices consist of an absorbent cellulose patch (where the substances are deposited), which is adhered to the skin by an adjacent adhesive. The device is hypoallergenic and waterproof; besides that, each device has an imprinted individual code and once removed cannot be re-attached to the skin - such characteristics aid the maintenance of chain of custody; the latter refers to the chronological documentation of the sample from the time of collection until the receivement by the laboratory [83], recording the sequence of custody, control, analysis and disposal of materials such as biological samples, used in analyses of forensic interest that prevent sample tampering [84]. The adhesive polyurethane layer protects the patch from external contaminations, while allows gas exchanges $\left(\mathrm{CO}_{2}, \mathrm{O}_{2}\right.$, water vapor) with the environment to occur, preventing the skin from being harmed. In this way, the device can stay attached to the skin up to 2 weeks [79, 81]. Prior application, the skin is usually cleaned with a swab soaked in $70 \%$ isopropanol, to remove previously existing substances from external environment [85]. Although being less common for drug monitoring applications, Macroduct ${ }^{\circledR}$ Sweat Analysis (ELITECH Wescor ${ }^{\circledR}$ Inc., South Logan, UT, USA) is another device dedicated to the collection of sweat. The system comprises a sweat inducer and collector, being originally designed for cystic fibrosis diagnosis through measurement of chloride ions in sweat. The device is composed of a $29 \mathrm{~mm}$ diameter disk equipped with a capillary plastic coil, responsible for the collection of fluid. Sweating induction is achieved by pilocarpine iontophoresis. Generally, the device in placed on subject's forearm and $60 \mu \mathrm{L}$ of sample can be obtained within $30 \mathrm{~min}$. Since iontophoresis is based on the application of electrical current to the skin, the process may be uncomfortable. On the other hand, this method allows prompt collection of sweat and standard sample volumes can be used for the following analysis [77].

Parent drugs-which can more easily cross physiological barriers-are expected to be detected in the sweat at greater concentrations than their corresponding hydrophilic metabolites. In addition, because sweat $\mathrm{pH}$ is more acidic than blood, basic drugs tend to accumulate in this fluid rather than acid substances [78]. Sweat volume normalization remains as a pending issue. Most of the existing approaches involves the use of sodium and potassium ions as internal reference for determination of sweating rate $[86,87]$. Sweat sample preparation for detection of drugs commonly involves a liquid-liquid extraction (LLE), using 
aqueous phosphate buffer or organic solvents (e.g., methanol). Then, the preliminary extract is subjected to clean-up to promote analyte pre-concentration. In this step, solidphase extraction (SPE) is frequently used. Sweat analysis is generally carried out using GC-MS or LC-MS. However, direct immunoassays such as radioimmune analysis and enzyme-linked immunosorbent assay (ELISA) can also be performed in this matrix [76], although confirmatory analysis relying on traditional techniques may be required. On-site sweat testing can be performed using Drugwipe $^{\circledR}$ (Securetec Detektions-Systeme AG, Neubiberg, Germany). This is a pen-size device which allows to screen controlled substances such as cocaine, opiates, cannabinoids, benzodiazepines and amphetamines/methamphetamines in saliva and skin/sweat. The system has a collector site, which transfers the sample to strips containing drug-specific antibodies by lateral flow. Once the test strip is immersed in water, results can be obtained within 3-8 min. This device has been mainly used by law enforcement for roadside screening for driving under the influence of drugs [88].

Sweat analysis has important applications in both forensic and clinical toxicology. Due to the noninvasive specimen's collection, cumulative register of substances, wider detection window and easy storage, sweat testing has been applied in the context of criminal justice system, to verify drug intake by subjects in parole/probation programs. Sweat can also be tested for drug monitoring in psychiatric outpatient service and recovering drug addicts. Additionally, sweat analysis can be used to evaluate occupational exposure to substances in the workplace, as well as to assess worker's exposure to prescribed substances [80, 89].

Several drugs of abuse have been determined in sweat specimens, such as cocaine, amphetamines and cannabinoids $[3,78]$. However, the literature on NPS testing in sweat specimens remains scarcely explored. A study on sweat analysis followed by a controlled oral administration of methamphetamine, showed that this drug was available in the matrix $2 \mathrm{~h}$ after dosing [90]. Doses at low and high concentrations implied in average concentrations of 63 and $307 \mathrm{ng} / \mathrm{patch}$ for methamphetamine, and 15 and $53.8 \mathrm{ng} /$ patch for amphetamine [90]. Another study involving the controlled intake of 3,4-methylenedioxymethamphetamine (MDMA) indicated that the parent drug was the main detected analyte, positive in $59.7 \%$ of the samples, at $<3007 \mathrm{ng} /$ patch. 3,4-methylenedioxyamphetamine (MDA) was found in $29.4 \%$ of the samples, at $<172 \mathrm{ng} /$ patch [91]. A review on amphetamines and methylenedioxy derivatives showed that limits of quantitation for these analytes ranged from 1.4 to $5 \mathrm{ng} / \mathrm{patch}$. Considering that a cut-off of $25 \mathrm{ng} / \mathrm{patch}$ is required to confirm the presence of such substances, the abovementioned methodologies seem to be suitable for sweat analysis in forensic practice [92].
Cocaine and codeine were the primary analytes found in sweat, after oral administration [82]. Peak concentrations were detected $4.5-24 \mathrm{~h}$ after drug intake [82]. Both analytes were identified $48 \mathrm{~h}$ after dosing. Concentrations of cocaine and codeine at elimination peak ranged from 33 to $3579 \mathrm{ng} /$ patch and from 11 to $1123 \mathrm{ng} / \mathrm{patch}$-for sweat collected from hand; and $22-1463 \mathrm{ng} / \mathrm{patch}$ and 12-360 ng/patch-for sweat collected from torso [82]. The developed method presented limits of quantitation ranging from 1.25 to $2.5 \mathrm{ng} /$ patch, for all analytes [82]. Use of crack among drug users was also evaluated using hand fast patches; cocaine was found in $92 \%$ of samples, comparable to a rate of $91 \%$ of positive cases according to immunoassay urinalysis. In $54 \%$ of the samples, crack metabolites could also be identified, and anhydroecgonine methyl ester was the substance that was most present in the sample [93].

Paired analysis of cannabinoids was performed on hair, urine and sweat [94]. As results, $\Delta^{9}$-tetrahydrocannabinol (THC) and 11-nor-9-carboxy-THC (THC-COOH) were found in all urine and hair samples [94]. THC was detected in all sweat samples, with concentrations ranging from 0.4 to $2.0 \mathrm{ng} /$ patch. Still regarding sweat, cannabinol $(0.4-0.5 \mathrm{ng} / \mathrm{patch})$ was found in $50 \%$ of cases and CBD $(0.4-0.6 \mathrm{ng} / \mathrm{patch})$ detected in $25 \%$ of samples, while THC-COOH could not be assessed in this matrix [95]. After oral administration of THC ( $14.8 \mathrm{mg} /$ day $)$, no daily or weekly patches presented concentrations superior to the limit of detection ( $0.4 \mathrm{ng} /$ patch), suggesting that sweat analysis is not the most sensitive approach to investigate THC exposure [94].

Cocaine and heroin were the main analytes detected in sweat after administration of these substances by intranasal and intravenous routes [96]. Lower concentrations of ecgonine methyl ester and benzoylecgonine were also detected after $2-48 \mathrm{~h}$ and $8 \mathrm{~h}$ from cocaine administration, respectively [96]. The metabolite 6-monoacetylmorphine (6-MAM) was rapidly detected after heroin administration and its concentration continued to increase with time as heroin levels decreased, indicating heroin hydrolysis in the collection patch [96]. Estimated limit of quantitation for heroin and metabolites was $2.5 \mathrm{ng} / \mathrm{patch}$ [96]. Among drug users, heroin and 6-MAM were found in concentrations up to 400 and $441.1 \mathrm{ng} /$ patch, respectively [96]. In another study, heroin and its metabolites were confirmed in $78.1 \%$ of sweat samples using GC-MS. The same samples were tested by ELISA analysis and correspondence was found in $90.6 \%$ of cases. Comparing ELISA analysis in sweat with enzyme multiplied immunoassay technique (EMIT) urinalysis, calculated sensitivity and specificity for sweat results on opiates were 68.6 and $86.1 \%$, respectively [97]. 


\section{Meconium}

Meconium is the first stool excreted by newborn. More than $98 \%$ of term infants pass their meconium within $48 \mathrm{~h}$ after birth [98]. However, delayed passage of meconium may occur in preterm infants and may cause intestinal obstruction $[99,100]$. Other uncommon situation is the meconium passage in utero as a signal of fetal stress (hypoxia) or a signal of advanced gastrointestinal maturation (postterm infant) [101].

Unlike feces, meconium is characterized as thick, sticky, greenish-black in color and lack of odor usually inherent to regular feces $[100,102]$. It is a highly complex matrix consisting mainly of water (70-75\% of total wet weight) with additional components such as lipids, plasma proteins, tissue debris, enzymes, ions, hemoglobin metabolites (bilirubin and porphyrins), steroids, bile acids, sterols and mucus glycoproteins. The contents of meconium are derived from swallowed amniotic fluid, secretions of the fetal alimentary tract (bile, pancreatic and intestinal secretions) and desquamation of cells from mouth, skin, alimentary tract, vernix and lanugo hair [103]. Illicit and licit drugs, used by mother during pregnancy, cross the placenta mainly by passive diffusion and, then, are accumulated in meconium by deposition via bile and the swallowed amniotic fluid [104]. Because meconium begins to form around 11-12th week of gestation (when a fetus begins swallowing amniotic fluid) and accumulates thereafter until birth [102, 105], it has been used as alternative matrix for assessing prenatal exposure to drugs (theoretically along the second and third trimesters of pregnancy) [102, 106, 107]. In general, the frequent and chronic exposure to drugs, especially during third trimester of pregnancy, are required to produce positive results for drug(s) in meconium [108]. Different patterns or proportional concentrations of the drug or metabolite in meconium may occur among newborns with similar exposure and, even between dizygotic twins. The mismatches may be explained by differences in fetal metabolism and placental differences [109, 110].

The main advantage of meconium as biological matrix is its wide detection window of in utero drug use. Others advantages of meconium include: noninvasive and easy sampling (meconium is collected from the diapers); a large amount of sample is available for collection (total amount range 20-60 g), and a small amount of sample is required for analysis (less than $1 \mathrm{~g}$ ) $[102,111]$. On the other hand, meconium testing has some limitations. It does not provide information about fetal drug exposure in the first trimester of pregnancy; meconium can be contaminated by urine or traditional feces (milk stool); usually it is not readily available for collection; meconium may be lost if is excreted in utero; it is not an homogenous sample (inhomogeneous distribution of drugs in meconium); irregular accumulation of meconium in the fetal gut (nearly $1 \mathrm{~g}$ of meconium accumulates until 23-26 weeks of pregnancy, $5 \mathrm{~g}$ until $27-32$ weeks and $80 \%$ of meconium accumulates after 38 weeks); drugs administered during labor and delivery may be detect as well as drugs administered to newborn before meconium collection [111-114].

Drugs may be screened in meconium using immunoassay techniques (e.g. ELISA, EMIT, biochip microarray) [115], then confirmed and quantified using GC-MS or liquid chromatography-tandem mass spectrometry (LC-MS/ MS) techniques [113]. As all complex matrices, meconium requires extensive pre-analytical processing to minimize matrix interferences and improve the detection potential for the analytes of interest. These processing involves sample homogenization (with water or organic solvents) and further extraction using, mainly, LLE followed by SPE, accelerated solvent extraction or headspace solid-phase microextraction (SPME) [114, 116].

Several licit and illicit drugs of forensic interest have been determined in meconium specimens. Assessment of fetal alcohol exposure can be performed via quantification of nonoxidative metabolites in meconium: EtG or FAEEs, represented by 9 compounds. Unlike EtG, FAEEs from mother do not across the placenta and thus FAEEs in meconium are produced by the fetus from ethanol that crossed the placenta, reflecting the true fetal alcohol exposure [117]. On the other hand, EtG in meconium is more stable at room temperature and its levels in meconium have been better correlated with EtG levels in maternal hair and with maternal self-report than FAEEs in meconium [118]. Himes et al. [119] concluded that maternal alcohol consumption at 19 weeks or more was better represented by meconium EtG levels equal to or higher than $30 \mathrm{ng} / \mathrm{g}$ rather than currently used FAEE cut-offs.

Others biomarkers in meconium have been determined for identification of fetal exposure to tobacco (nicotine and cotinine); cocaine, hydroxybenzoylecgonine, benzoylecgonine, ecgonine methyl ester and anhydroecgonine methyl ester); cannabis (THC-COOH); amphetamine, $p$-hydroxyamphetamine; methamphetamine $p$-hydroxymethamphetamine); heroin (6-MAM, morphine and codeine) [107, 108, 110]. In regards to NPS, in the literature, there are only a few reports on analytical method development and detection in authentic specimens (e.g., synthetic cathinones [120-122]).

Meconium drug testing has some limitations that should be considered in the interpretation of the results. A false negative result may be due to instability of some analytes in meconium (e.g., FAEEs, 6-MAM); inappropriately high cut-off concentration; delayed meconium collection (collected sample is transition stool or milk stool); inappropriate analytical targets (analytes not common in urine can improve detection of drug in meconium, e.g., 
$m$-hydroxybenzoylecgonine and $p$-hydroxymethamphetamine) $[110,123]$. A false positive result for FAEEs may be due to delayed meconium collection because of contamination of meconium with dietary components of stool produced after birth and ethanol-producing microorganisms. Then, in this case, there is a recommendation that meconium collection should be performed until $24 \mathrm{~h}$ after birth [124]. Despite these limitations, meconium drug testing remains the "gold standard" for identifying in utero drug exposure (drug exposure detection in newborn). More studies are needed to associate meconium drug concentration with the degree of exposure or the severity of outcomes [114].

\section{Breast milk}

Human breast milk (HBM) is a complex fluid with high lipoprotein content, and is considered as the best nutrient for newborns aging from 6 months to 2 years old and also works as a complement to solid food [125-127]. Several exogenous compounds arising from mothers' consumption habits may be incorporated into breast milk during lactation, and breastfed babies may be exposed to the substances such as medication, pesticides, toxic metals and drugs of abuse [128-131]. In forensic toxicology, HBM is an alternative matrix for drug analysis with a short detection window, being useful to investigate mother's recent drug use (hours) and to assess the infant exposure to substances that may be harmful for their cognitive and motor development [132, 133]. It is also noteworthy that the noninvasive and easy collection of this sample and the importance of the analytical results complement the information from self-reports $[134,135]$. The benefits associated to breastfeeding for both mother and infant, including decreased rates of infections and severe comorbidities, must be weighed against the effects of the drug on the infant to make the best decision for both mother and child's health.

Advances in analytical chemistry provided new techniques that offer adequate sensitivity, environmental friendliness and ability to fast process many samples of different complexities [136]. In a recent review about HBM and psychoactive substances by Santos and De Martinis [137], most studies published over the last 10 years reported analysis of HBM using LC-MS/MS, and the most commonly employed sample preparation techniques were SPE, protein precipitation, LLE and some miniaturized techniques. More detailed information is summarized and published elsewhere [137]. More recently, Behpour et al. [138] developed a gelbased electromembrane microextraction (EME) coupled with switchable hydrophilicity solvent-based liquid-liquid microextraction procedure to quantify antidepressants in breast milk, serum and wastewater samples. The technique provided growth of enrichment factor over original EME, reducing limits of detection (LODs) and limits of quantification (LOQs); and the use of low volume of organic solvent allowed the analysis by gas chromatography with flame ionization detector (GC-FID), which usually cannot be performed with EME due to its aqueous acceptor phase, which is often analyzed by high-performance liquid chromatography with ultraviolet detection (HPLC-UV) [138]. Sempio et al. [139] developed an LC-MS/MS method for quantification of 12 cannabinoids in 30 samples from a clinical study and 6 samples from a breast milk bank and compared the analysis' results with ELISA immunological assay. They performed protein precipitation followed by online extraction using $0.2 \mathrm{~mL}$ of sample, achieving lower LOQs than ELISA's LODs for THC-COOH and adequate absolute recoveries [139]. Results showed that the 30 clinical samples tested negative on ELISA, but all of them tested positive for THC using LC-MS/MS, and in many of them, 11-hydroxy$\Delta^{9}$-tetrahydrocannabinol (THC-OH), THC-COOH, CBD and cannabigerol were also detected [139]. All the 6 milk bank samples tested negative on ELISA and on LC-MS/MS as well [139]. The results of this study show the importance of correctly interpreting the results of screening tests and the need of greater implementation of quantitative analyses in the routine of toxicological assessment. The absence of THC-COOH according to ELISA would mean that there was no recent consumption of cannabis, while a highly sensitive technique showed the opposite result, suggesting the possibility of infant exposure [139].

The excretion of substances into HBM depends on physicochemical characteristics of the compound, including molecular weight, ionization degree (pKa) and the solubility in lipids as well as the $\mathrm{pH}$ of milk (6.5-6.8) [140]. For instance, THC, the major psychoactive compound of cannabis, has low molecular weight and high pKa value, is lipid soluble and $99 \%$ is protein bound. Those factors cause the THC transfer into breast milk and its accumulation in lipidfilled portions as well [141]. Cannabis is the most consumed drug of abuse in pregnancy and after birth, but still there is no information about how much the amount present in HBM is related to the concentration of THC in cannabis or its joints, the frequency of use and the concentration in maternal plasma [127, 142]. Two surveys evaluated the effect of maternal marijuana use while breastfeeding, and they found that infants exposed to marijuana were slightly smaller and had decreased points in motor scores, but marijuana use during pregnancy might have caused confounded results [143, 144]. Some studies reported cases of infant cocaine intoxication through breast milk presenting acute effects as agitation and seizures, neonatal abstinence syndrome in cases of opioid intoxication, and sedation and breast sucking difficulty due to exposure to cannabis [145, 146]. Several clinical studies about infant exposure through breastfeeding are summarized in Drugs and Lactation Database [147]. 
The lack of studies shows the importance of public policies to inform population about the consequences of infants exposed to drugs of abuse through breast milk. The risk assessment in breastfed babies requires more quantitative data, as well as an understanding of the factors determining exposure after oral maternal ingestion followed by excretion into HBM. Furthermore, confirmatory toxicological analysis should be included in quality control routines of breast milk samples (complementing self-reports and screening tests) to maintain its quality and the importance of breastfeeding. In addition, combining clinical data with in silico modeling and simulation approaches (such as physiologically based pharmacokinetic model, chemometrics and others) is an emerging and powerful strategy for predicting drug mechanisms and toxic effects in human body [148].

\section{Vitreous humor}

Vitreous humor (VH) is an alternative matrix commonly used in postmortem toxicological analyses and its application in forensic analysis started in the 1960s [149]. Since then, many analyses in $\mathrm{VH}$ have been conducted, including ethanol, illicit drugs and endogenous compounds [150]. One of the interests of using $\mathrm{VH}$ in toxicological analysis is especially when traditional matrices, such as blood or urine, are unavailable or under inappropriate conditions for analysis [151]. Casework involving embalmed, burned or highly decomposed bodies are such examples [152].

$\mathrm{VH}$ is a gelatinous liquid filling the eyeball, between the crystalline lens and the retina [2, 149][143]. The composition of $\mathrm{VH}$ is primarily water (around 98\%), including other components such as lipids, electrolytes, polysaccharides, proteins and other substances [149, 151]. Drugs present in circulating blood may reach the VH through the bloodretinal barrier, by passive diffusion or active transport [153, 154]. Drugs are able to reach the VH only if in free form (not bound to proteins) [154], and thus drugs exhibiting a low rate of protein binding are present in $\mathrm{VH}$ at greater levels $[154,155]$. On the other hand, if a drug is likely to bind to proteins, it should not be expected in VH [154].

The application of $\mathrm{VH}$ in forensic analyses is based on several advantages of this matrix. In comparison to other postmortem fluids, the composition of VH makes it a cleaner matrix, with less interferents [2, 153], being an aqueous matrix with minimal protein contents [151]. VH also has a low number of cells and lacks of blood vessels [153], avoiding potential infections from the blood [155]. Another advantage of $\mathrm{VH}$ is its prolonged stability in comparison to other matrices $[2,156]$. The location of $\mathrm{VH}$ is also an advantage, as it is located in a body compartment protected against contamination and microbial activity [149, 151], especially being remotely located from gastrointestinal tract [150]. In comparison, postmortem blood is more likely than $\mathrm{VH}$ to suffer microbial activity and degradation [157] and autolytic processes are delayed in $\mathrm{VH}$ in relation to blood [158]. After death, bacteria present in the gut, lung, oral cavity and other microbiomes, and also environmental bacteria may infect other surrounding tissues and fluids, whereas in $\mathrm{VH}$ this process occur to a lesser extent, reducing the contamination and increasing the stability of this specimen [149]. For example, in a study by Harper [157], postmortem blood and VH were collected from 51 decedents and microbiological analyses revealed no significant amounts of bacteria or fungi in $\mathrm{VH}$ and high diversity of microorganisms in 32 postmortem blood specimens. This is particularly interesting for ethanol testing, since the postmortem formation of ethanol is unlikely in VH [159]. In VH, there is no esterase activity [160], which also contributes to an increased stability of compounds in this specimen. Although the use of $\mathrm{VH}$ has several analytical benefits, drug testing in $\mathrm{VH}$ has a few limitations. The volume available for sampling is limited and the blood-retinal barrier may restricts the incorporation of drugs into VH [156, 159]. In addition, in violent death cases a rupture of the eyeball may occur, with loss of $\mathrm{VH}$.

The collection of $\mathrm{VH}$ is performed by gentle introduction of a sterilized needle into the eyeball followed by fluid aspiration [149], penetrating in approximately $2 \mathrm{~cm}$ [2] and avoiding the collection of retinal or iris cells [153]. Usually sufficient volumes are collected for analysis but the volume may be reduced during postmortem body dehydration process [149]. Around 2-2.5 mL of VH is available in each eyeball [152]. Water or saline solution may be used as surrogate for $\mathrm{VH}$, to provide the physical aspect of the eyeball, after VH is removed [153, 161], especially for funeral purposes. Usually samples are stored in polypropylene or glass tubes, without adding any preservatives or adding fluorides (sodium or potassium), oxalates (calcium or potassium) or ethylenediaminetetraacetic acid (EDTA) disodium salt [151]. For example, in a study by Rees et al. [160], it has been shown that sodium fluoride addition to $\mathrm{VH}$ provided greater stabilities for 6-MAM, which could be explained due to reduction of bacterial activity and putrefaction in this sample.

In general, $\mathrm{VH}$ testing in a forensic toxicology setting does not differ from blood or urine testing and several methods developed for blood/urine testing have been adopted in $\mathrm{VH}$ analysis [154]. As previously mentioned, the protein and aqueous contents in $\mathrm{VH}$ samples tend to reduce the complexity of sample preparation [151]. A systematic contemporary review covering methods used in the preparation and analysis of $\mathrm{VH}$ specimens has been recently published by Wójtowicz et al. [151]. In general, several extraction techniques have been explored for VH samples' preparation. In the literature, there are several SPE-based methods available proposed for extracting drugs from VH specimens [154-156, 
162-168]. LLE has also been reported and explored for VH samples [169-175]. Other techniques have been less frequently explored such as microwave assisted extraction [176], disposable pipette extraction [177], supercritical fluid extraction [178], dispersive liquid-liquid microextraction [179] and liquid-phase microextraction (LPME) [180].

A diverse repertoire of analytical techniques has been reported in the analysis of VH specimens. Chromatography coupled to mass spectrometry-based methods have been frequently used due to its high sensitivity, selectivity and accuracy [151]. Gas chromatographic techniques used in separation and analysis of VH samples include GC-MS [154, 156, 163, 164, 167-170, 180-182], gas chromatography with nitrogen-phosphorus detector (GC-NPD) [170, 177] and GC-FID [159, 166]. Gas chromatography coupled to tandem ion trap mass spectrometry (GC-MS/MS) has also been applied in the analysis of cocaine in sheep's VH [183]. Analytical methods using LC have been developed as well, using diverse techniques such as HPLC-UV [162], highperformance liquid chromatography-diode array detection [155, 171, 176, 179, 184], LC with fluorescence detector (e.g., [174]), LC-MS/MS (e.g., [173, 175, 185]) and liquid chromatography coupled to time-of-flight mass spectrometry (LC-TOF-MS) [165]. Comprehensive screening of VH (covering a large range of compounds) and comparison to other traditional matrices (e.g. blood or urine) have been performed by GC-MS [156] or by LC-TOF-MS [165]. Separation methods based on capillary electrophoresis have also been explored for drug testing in VH such as a capillary electrophoresis with diode array detection method published by Costa et al. [172]. Besides instrumental separation methods, immunoassays applied in the analysis of other biological fluids have also been explored for VH [170, 186-189].

Over the years, VH has been successfully used in forensic casework, for illicit drugs and NPS testing. Several classic drugs of abuse have been detected in authentic $\mathrm{VH}$ specimens such as the following examples: ethanol [159, 181, 190], cocaine and its metabolites [155, 164, 166, 172, 176, 181, 190-192], opioids and/or their metabolites [155, $167,168,173,176,177,182,185,190]$, amphetamine and/ or methamphetamine [164, 173, 190], MDA derivatives [169], ketamine [172], phencyclidine [154, 170], LSD and its metabolites [175], $\gamma$-hydroxybutyric acid [193], benzodiazepines [171, 173, 184, 190], antidepressants [173, 180, 194, 195] and barbiturates [196]. On the other hand, VH does not seem to be a good biological matrix for investigating cannabinoids [151]. In a study by Saenz et al. [197], THC and THC-OH were detected only in blood and/ or urine but not in VH in two cases [197]. In these same two cases, THC-COOH was detected in blood, urine and $\mathrm{VH}$ in one case whereas in the other case THC-COOH was detected in blood and urine only [197]. Similarly, in another study by Peres et al. [164], THC and THC-COOH were detected in three cases in whole blood specimens but not in VH. Other studies in the literature reported findings regarding THC and its metabolite distribution into $\mathrm{VH}$ in agreement with these observations [170, 198]. This can be rationalized due to strong affinity for plasma proteins and lipophilicity exhibited by THC, which reduces the incorporation of THC into aqueous specimens, such as VH [164, 199]. In addition, Lin and Lin [198] observed low vitreous concentrations of THC-COOH, a hydrophobic character compound. In regard to NPS, VH has also been implemented in toxicological analysis for a different classes including fentanyl and non-fentanyl opioids [200-207], synthetic cathinones [208-212], designer benzodiazepines [190], 5-(2-aminopropyl)indole [213] and phenethylamines [214-216].

\section{Other alternative matrices}

Oral fluid, meconium, hair, sweat, breast milk and VH are commonly reported and implemented in forensic toxicological analyses as alternative matrices. However, this range of alternative specimens is not exhaustive and other fluids have been explored and proposed. The use of other fluids and tissues including bile [5], nails [217], bone marrow [218], umbilical cord [107, 113, 219] and others, as alternative matrices has been reviewed and discussed in the literature. In addition, tooth is another matrix that has been explored in forensic toxicology, especially considering its ability to resist to postmortem decomposition, environmental changes and other agents [220]. Examples of drugs or metabolites recently reported in human teeth include cocaine, benzoylecgonine, morphine, 6-MAM, THC, CBN, CBD [220], amphetamine, MDMA, morphine, codeine, norcodeine, methadone, 2-ethylidene1,5-dimethyl-3,3-diphenylpyrrolidine, fentanyl, tramadol, diazepam, nordiazepam and promethazine [221]. Another alternative specimen more recently explored is cerumen or earwax. Cocaine and metabolites, methamphetamine, opioids, cannabinoids, benzodiazepines, antiepileptics and antipsychotics are examples of substances recently reported in authentic cerumen specimens [222, 223]. Meier et al. [222] have also detected the NPS 4-fluoroamphetamine in cerumen specimens. The collection of cerumen is less invasive than that of other biofluids [223] and the detection window is longer when compared to urine [222]. Synovial fluid obtained from articular joints, especially knee joints, has been also proposed as an alternative matrix for the investigation of drugs/metabolites such as morphine, codeine, cocaine, 6-MAM, benzoylecgonine and ecgonine methyl ester [224]. 


\section{Conclusions}

The selection of specimens in toxicological analyses is a critical step. Understanding the properties of both target analyte and matrix is very important, to select the most appropriate biological fluid/tissue for the case under investigation. Alternative biological matrices are biological fluids/tissues that can provide additional information and advantages in comparison to blood and urine testing, in several aspects such as sample collection, detection window and complexity of sample preparation/analysis. In addition, these matrices can be collected and analyzed when blood and urine are not available. However, each one of these alternative matrices has its own characteristics, advantages and limitations, which need to be considered. The perspective in forensic toxicology is that alternative matrices will be more frequently explored in the future. For example, the Organization of Scientific Area Committees for Forensic Science (OSAC) recommend research on alternative matrices for the improvement of forensic toxicology [225]. Therefore, further research is still needed to provide analytical methods and better understanding on the behavior of drugs in these matrices, especially for emerging NPS.

Acknowledgements This study was financed in part by the Coordenação de Aperfeiçoamento de Pessoal de Nível Superior-Brasil (CAPES) - Finance Code 001 (Fellowships and Grant Pró-Forenses n. 25/2014) and Grant \#2017/18021-5, 2013/19653-4 and 2017/103870, São Paulo Research Foundation (FAPESP).

\section{Declarations}

Conflict of interest The authors declare that there are no conflicts of interest in regards to this manuscript.

Ethical approval This article does not contain any studies with human participants or animals performed by any of the authors.

Open Access This article is licensed under a Creative Commons Attribution 4.0 International License, which permits use, sharing, adaptation, distribution and reproduction in any medium or format, as long as you give appropriate credit to the original author(s) and the source, provide a link to the Creative Commons licence, and indicate if changes were made. The images or other third party material in this article are included in the article's Creative Commons licence, unless indicated otherwise in a credit line to the material. If material is not included in the article's Creative Commons licence and your intended use is not permitted by statutory regulation or exceeds the permitted use, you will need to obtain permission directly from the copyright holder. To view a copy of this licence, visit http://creativecommons.org/licenses/by/4.0/.

\section{References}

1. Frederick DL (2012) Toxicology testing in alternative specimen matrices. Clin Lab Med 32:467-492. https://doi.org/10.1016/j. cll.2012.06.009

2. Manousi N, Samanidou V (2021) Green sample preparation of alternative biosamples in forensic toxicology. Sustain Chem Pharm 20:100388. https://doi.org/10.1016/j.scp.2021.100388

3. Gallardo E, Queiroz JA (2008) The role of alternative specimens in toxicological analysis. Biomed Chromatogr 22:795-821. https://doi.org/10.1002/bmc.1009

4. Moriya F (2005) Alternative specimens. In: Suzuki O, Watanabe $\mathrm{K}$ (eds) Drugs and poisons in humans: handbook of practical analysis. Springer-Verlag, Berlin/Heidelberg, pp 9-15

5. Bévalot F, Cartiser N, Bottinelli C, Guitton J, Fanton L (2016) State of the art in bile analysis in forensic toxicology. Forensic Sci Int 259:133-154. https://doi.org/10.1016/j.forsciint.2015. 10.034

6. Aps JKM, Martens LC (2005) Review: the physiology of saliva and transfer of drugs into saliva. Forensic Sci Int 150:119-131. https://doi.org/10.1016/j.forsciint.2004.10.026

7. de Almeida PDV, Grégio AMT, Machado MÅN, de Lima AAS, Azevedo LR (2008) Saliva composition and functions: a comprehensive review. J Contemp Dent Pract 9:72-80. https://doi. org/10.5005/jcdp-9-3-72 (open access article)

8. da Costa BRB, Santos Júnior WJR, Maximiano IF, Gomes NC, Freitas BT, De Martinis BS (2021) Application of microextraction techniques in alternative biological matrices with focus on forensic toxicology: a review. Bioanalysis 13:45-64. https:// doi.org/10.4155/bio-2020-0241

9. Elmongy H, Abdel-Rehim M (2016) Saliva as an alternative specimen to plasma for drug bioanalysis: a review. Trends Analyt Chem 83:70-79. https://doi.org/10.1016/j.trac.2016.07.010

10. Yoshizawa JM, Schafer CA, Schafer JJ, Farrell JJ, Paster BJ, Wong DTW (2013) Salivary biomarkers: toward future clinical and diagnostic utilities. Clin Microbiol Rev 26:781-791. https://doi.org/10.1128/CMR.00021-13 (open access article)

11. Higashi T (2012) Salivary hormone measurement using LC/ MS/MS: specific and patient-friendly tool for assessment of endocrine function. Biol Pharm Bull 35:1401-1408. https:// doi.org/10.1248/bpb.b212009 (open access article)

12. Malaca S, Busardò FP, Gottardi M, Pichini S, Marchei E (2019) Dilute and shoot ultra-high performance liquid chromatography tandem mass spectrometry (UHPLC-MS/MS) analysis of psychoactive drugs in oral fluid. J Pharm Biomed Anal 170:6367. https://doi.org/10.1016/j.jpba.2019.02.039

13. Bosker WM, Huestis MA (2009) Oral fluid testing for drugs of abuse. Clin Chem 55:1910-1931. https://doi.org/10.1373/ clinchem.2008.108670 (open access article)

14. Martí-Álamo S, Mancheno-Franch A, Marzal-Gamarra C, Carlos-Fabuel L (2012) Saliva as a diagnostic fluid. Literature review. J Clin Exp Dent 4:e237-e243. https://doi.org/10.4317/ jced.50865 (open access article)

15. Bellagambi FG, Lomonaco T, Salvo P, Vivaldi F, Hangouët M, Ghimenti S, Biagini D, Di Francesco F, Fuoco R, Errachid A (2020) Saliva sampling: methods and devices. An overview. Trends Analyt Chem 124:115781. https://doi.org/10.1016/j. trac.2019.115781

16. Bordin DCM, da Silva Souza Monedeiro FF, de Campos EG, Alves MNR, Bueno LHP, de Martinis BS (2015) Técnicas de preparo de amostras biológicas com interesse forense. Sci Chromatogr 7:125-143. https://doi.org/10.4322/sc.2015.022 (in Portuguese) (open access article)

17. da Costa BRB, De Martinis BS (2020) Analysis of urinary VOCs using mass spectrometric methods to diagnose cancer: 
a review. Clin Mass Spectrom 18:27-37. https://doi.org/10. 1016/j.clinms.2020.10.004 (open access article)

18. Seidi S, Rezazadeh M, Alizadeh R (2019) Miniaturized sample preparation methods for saliva analysis. Bioanalysis 11:119148. https://doi.org/10.4155/bio-2018-0160

19. Allen KR (2011) Screening for drugs of abuse: which matrix, oral fluid or urine? Ann Clin Biochem 48:531-541. https://doi. org/10.1258/acb.2011.011116 (open access article)

20. Desrosiers NA, Huestis MA (2019) Oral fluid drug testing: analytical approaches, issues and interpretation of results. J Anal Toxicol 43:415-443. https://doi.org/10.1093/jat/bkz048 (open access article)

21. Khurshid Z, Zohaib S, Najeeb S, Zafar MS, Slowey PD, Almas K (2016) Human saliva collection devices for proteomics: an update. Int J Mol Sci 17:846. https://doi.org/10.3390/ijms1 7060846 (open access article)

22. Bueno LHP, da Silva RHA, Azenha AV, de Souza Dias MC, De Martinis BS (2014) Oral fluid as an alternative matrix to determine ethanol for forensic purposes. Forensic Sci Int 242:117122. https://doi.org/10.1016/j.forsciint.2014.06.024

23. Wille SMR, Raes E, Lillsunde P, Gunnar T, Laloup M, Samyn N, Christophersen AS, Moeller MR, Hammer KP, Verstraete AG (2009) Relationship between oral fluid and blood concentrations of drugs of abuse in drivers suspected of driving under the influence of drugs. Ther Drug Monit 31:511-519. https://doi.org/10. 1097/FTD.0b013e3181ae46ea

24. Gjerde H, Langel K, Favretto D, Verstraete AG (2015) Detection of illicit drugs in oral fluid from drivers as biomarker for drugs in blood. Forensic Sci Int 256:42-45. https://doi.org/10.1016/j. forsciint.2015.06.027

25. Busardo FP, Pichini S, Pellegrini M, Montana A, Lo Faro AF, Zaami S, Graziano S (2018) Correlation between blood and oral fluid psychoactive drug concentrations and cognitive impairment in driving under the influence of drugs. Curr Neuropharmacol 16:84-96. https://doi.org/10.2174/1570159X156661708281 62057

26. Milman G, Barnes AJ, Lowe RH, Huestis MA (2010) Simultaneous quantification of cannabinoids and metabolites in oral fluid by two-dimensional gas chromatography mass spectrometry. J Chromatogr A 1217:1513-1521. https://doi.org/10.1016/j. chroma.2009.12.053

27. Bessonneau V, Boyaci E, Maciazek-Jurczyk M, Pawliszyn J (2015) In vivo solid phase microextraction sampling of human saliva for non-invasive and on-site monitoring. Anal Chim Acta 856:35-45. https://doi.org/10.1016/j.aca.2014.11.029

28. Swortwood MJ, Newmeyer MN, Andersson M, Abulseoud OA, Scheidweiler KB, Huestis MA (2017) Cannabinoid disposition in oral fluid after controlled smoked, vaporized, and oral cannabis administration. Drug Test Anal 9:905-915. https://doi.org/10. 1002/dta.2092

29. Pacifici R, Pichini S, Pellegrini M, Tittarelli R, Pantano F, Mannocchi G, Rotolo MC, Busardò FP (2019) Determination of cannabinoids in oral fluid and urine of "light cannabis" consumers: a pilot study. Clin Chem Lab Med 57:238-243. https://doi.org/ 10.1515/cclm-2018-0566

30. Sorribes-Soriano A, Esteve-Turrillas FA, Armenta S, Amorós P, Herrero-Martínez JM (2019) Amphetamine-type stimulants analysis in oral fluid based on molecularly imprinting extraction. Anal Chim Acta 1052:73-83. https://doi.org/10.1016/j.aca.2018. 11.046

31. Risoluti R, Gullifa G, Buiarelli F, Materazzi S (2020) Real time detection of amphetamine in oral fluids by MicroNIR/Chemometrics. Talanta 208:120456. https://doi.org/10.1016/j.talanta. 2019.120456

32. Tavares LS, Carvalho TC, Romão W, Vaz BG, Chaves AR (2018) Paper spray tandem mass spectrometry based on molecularly imprinted polymer substrate for cocaine analysis in oral fluid. J Am Soc Mass Spectrom 29:566-572. https://doi.org/10.1007/ s13361-017-1853-2

33. D'Elia V, Montalvo G, Ruiz CG, Ermolenkov VV, Ahmed Y, Lednev IK (2018) Ultraviolet resonance Raman spectroscopy for the detection of cocaine in oral fluid. Spectrochim Acta Part A Mol Biomol Spectrosc 188:338-340. https://doi.org/10.1016/j. saa.2017.07.010

34. Herrera-Gómez F, García-Mingo M, Colás M, González-Luque JC, Álvarez FJ (2018) Opioids in oral fluid of Spanish drivers. Drug Alcohol Depend 187:35-39. https://doi.org/10.1016/j. drugalcdep.2018.02.016

35. Griswold MK, Chai PR, Krotulski AJ, Friscia M, Chapman BP, Varma N, Boyer EW, Logan BK, Babu KM (2017) A novel oral fluid assay (LC-QTOF-MS) for the detection of fentanyl and clandestine opioids in oral fluid after reported heroin overdose. J Med Toxicol 13:287-292. https://doi.org/10.1007/ s13181-017-0632-6

36. Petrides AK, Melanson SEF, Kantartjis M, Le RD, Demetriou CA, Flood JG (2018) Monitoring opioid and benzodiazepine use and abuse: is oral fluid or urine the preferred specimen type? Clin Chim Acta 481:75-82. https://doi.org/10.1016/j.cca. 2018.02.034

37. Sorribes-Soriano A, Valencia A, Esteve-Turrillas FA, Armenta S, Herrero-Martínez JM (2019) Development of pipette tipbased poly(methacrylic acid-co-ethylene glycol dimethacrylate) monolith for the extraction of drugs of abuse from oral fluid samples. Talanta 205:120158. https://doi.org/10.1016/j.talanta. 2019.120158

38. Rocchi R, Simeoni MC, Montesano C, Vannutelli G, Curini R, Sergi M, Compagnone D (2018) Analysis of new psychoactive substances in oral fluids by means of microextraction by packed sorbent followed by ultra-high-performance liquid chromatography-tandem mass spectrometry. Drug Test Anal 10:865-873. https://doi.org/10.1002/dta.2330

39. Bianchi F, Agazzi S, Riboni N, Erdal N, Hakkarainen M, Ilag LL, Anzillotti L, Andreoli R, Marezza F, Moroni F, Cecchi R, Careri M (2019) Novel sample-substrates for the determination of new psychoactive substances in oral fluid by desorption electrospray ionization-high resolution mass spectrometry. Talanta 202:136-144. https://doi.org/10.1016/j.talanta.2019.04.057

40. Gomez-Roig MD, Marchei E, Sabra S, Busardò FP, Mastrobattista L, Pichini S, Gratacós E, Garcia-Algar O (2018) Maternal hair testing to disclose self-misreporting in drinking and smoking behavior during pregnancy. Alcohol 67:1-6. https://doi.org/10. 1016/j.alcohol.2017.08.010

41. Bertol E, Vaiano F, Boscolo-Berto R, Fioravanti A, Palumbo D, Catalani V, Mari F, Patussi V, Serpelloni G (2017) Alcohol, caffeine, and nicotine consumption in adolescents: hair analysis versus self-report. Am J Drug Alcohol Abuse 43:341-349. https://doi.org/10.1080/00952990.2016.1216556

42. Tsuji M, Kanda H, Hayakawa T, Mori Y, Ito T, Hidaka T, Kakamu T, Kumagai T, Osaki Y, Kawazoe M, Sato S, Fukushima $\mathrm{T}$ (2017) Nicotine cut-off value in human hair as a tool to distinguish active from passive smokers: a cross-sectional study in Japanese men. Cancer Biomark 20:41-48. https://doi.org/10. 3233/CBM-170004

43. Albermann ME, Madea B, Musshoff F (2014) A SPME-GC/ MS procedure for the determination of fatty acid ethyl esters in hair for confirmation of abstinence test results. J Chromatogr Sci 52:955-960. https://doi.org/10.1093/chromsci/bmt146 (open access article)

44. Bastiani MF, Lizot LLF, Da Silva ACC, Hahn RZ, Dries SS, Perassolo MS, Antunes MV, Linden R (2020) An optimized solid-phase microextraction and gas chromatography-mass 
spectrometry assay for the determination of ethyl palmitate in hair. J Anal Toxicol 44:402-409. https://doi.org/10.1093/jat/ bkz085

45. Crunelle CL, Yegles M, van Nuijs ALN, Covaci A, De Doncker M, Maudens KE, Sabbe B, Dom G, Lambert WE, Michielsen P, Neels H (2014) Hair ethyl glucuronide levels as a marker for alcohol use and abuse: a review of the current state of the art. Drug Alcohol Depend 134:1-11. https://doi.org/10.1016/j.druga lcdep.2013.10.008

46. Pascali JP, Palumbo D, Umani Ronchi F, Mari F, Fioravanti A, Bertol E (2020) Ethyl glucuronide concentration in hair of detainees: a preliminary study. J Forensic Sci 65:189-192. https://doi.org/10.1111/1556-4029.14132

47. Al-Zahrani MA, Al-Asmari AI, Al-Zahrani FF, Torrance HJ, Watson DG (2021) Quantification of cannabinoids in human hair using a modified derivatization procedure and liquid chromatography-tandem mass spectrometry. Drug Test Anal. https:// doi.org/10.1002/dta.3005 [ahead of print]

48. Gerace E, Bakanova SP, Di Corcia D, Salomone A, Vincenti M (2021) Determination of cannabinoids in urine, oral fluid and hair samples after repeated intake of CBD-rich cannabis by smoking. Forensic Sci Int 318:110561. https://doi.org/10. 1016/j.forsciint.2020.110561

49. Younas A, Nawaz MA, Hafeez A, Ijaz A, Aamir M, Malik SS, Asif N, Manan A (2020) Diagnostic accuracy of cannabinoid testing by liquid chromatography-tandem mass spectrometry in human hair. J Pak Med Assoc 70:2346-2351. https://doi.org/ 10.47391/JPMA.01144

50. Shah I, Al-Dabbagh B, Salem AE, Hamid SAA, Muhammad N, Naughton DP (2019) A review of bioanalytical techniques for evaluation of cannabis (Marijuana, weed, Hashish) in human hair. BMC Chem 13:106. https://doi.org/10.1186/s13065-0190627-2 (open access article)

51. Müller VV, Hahn RZ, de Lima Feltraco Lizot L, Schneider A, da Silva CP, Gerbase FE, Pereira D, Linden R, Antunes MV (2020) Validation of an analytical method for the simultaneous determination of 16 drugs and metabolites in hair in the context of driving license granting. Forensic Sci Int 315:110428. https://doi.org/10.1016/j.forsciint.2020.110428

52. Minoli M, Casati S, Angeli I, Ravelli A, Rota P, Allevi P, Orioli M (2019) Analysis of hydroxy-cocaine metabolites as evidence of cocaine consumption: identification by parent ion search and quantitation by UHPLC-MS/MS in hair. J Pharm Biomed Anal 172:167-174. https://doi.org/10.1016/j.jpba.2019.04.028

53. Pego AMF, Roveri FL, Kuninari RY, Leyton V, Miziara ID, Yonamine M (2017) Determination of cocaine and its derivatives in hair samples by liquid phase microextraction (LPME) and gas chromatography-mass spectrometry (GC-MS). Forensic Sci Int 274:83-90. https://doi.org/10.1016/j.forsciint.2016. 12.024

54. Franz T, Scheufler F, Stein K, Uhl M, Dame T, Schwarz G, Sachs H, Skopp G, Musshoff F (2018) Determination of hydroxy metabolites of cocaine from hair samples and comparison with street cocaine samples. Forensic Sci Int 288:223-226. https://doi. org/10.1016/j.forsciint.2018.04.007

55. Kwon NH, Lee YR, Kim HS, Cheong JC, Kim JY (2019) Hybrid solid-phase extraction for selective determination of methamphetamine and amphetamine in dyed hair by using gas chromatography-mass spectrometry. Molecules 24:2501. https://doi.org/ 10.3390/molecules 24132501 (open access article)

56. Argente-García A, Moliner-Martínez Y, Campíns-Falcó P, Verdú-Andrés J, Herráez-Hernández R (2016) Determination of amphetamines in hair by integrating sample disruption, cleanup and solid phase derivatization. J Chromatogr A 1447:47-56. https://doi.org/10.1016/j.chroma.2016.04.036
57. Burgueño MJ, Alonso A, Sánchez S (2016) Amphetamines and cannabinoids testing in hair: evaluation of results from a two-year period. Forensic Sci Int 265:47-53. https://doi.org/10.1016/j. forsciint.2016.01.003

58. Kyriakou C, Pellegrini M, García-Algar O, Marinelli E, Zaami S (2017) Recent trends in analytical methods to determine new psychoactive substances in hair. Curr Neuropharmacol 15:663681. https://doi.org/10.2174/1570159X15666161111112545

59. Salomone A, Gazzilli G, Di Corcia D, Gerace E, Vincenti M (2016) Determination of cathinones and other stimulant, psychedelic, and dissociative designer drugs in real hair samples. Anal Bioanal Chem 408:2035-2042. https://doi.org/10.1007/ s00216-015-9247-4

60. Mantinieks D, Gerostamoulos D, Wright P, Drummer O (2018) The effectiveness of decontamination procedures used in forensic hair analysis. Forensic Sci Med Pathol 14:349-357. https://doi. org/10.1007/s12024-018-9994-6

61. Xiang P, Shen M, Drummer OH (2015) Review: drug concentrations in hair and their relevance in drug facilitated crimes. J Forensic Leg Med 36:126-135. https://doi.org/10.1016/j.jflm. 2015.09.009

62. Ferreira C, Paulino C, Quintas A (2019) Extraction procedures for hair forensic toxicological analysis: a mini-review. Chem Res Toxicol 32:2367-2381. https://doi.org/10.1021/acs.chemrestox. $9 \mathrm{~b} 00301$

63. Tzatzarakis MN, Alegakis AK, Kavvalakis MP, Vakonaki E, Stivaktakis PD, Kanaki K, Vardavas AI, Barbounis EG, Tsatsakis AM (2016) Comparative evaluation of drug deposition in hair samples collected from different anatomical body sites. J Anal Toxicol 41:214-223. https://doi.org/10.1093/jat/bkw127 (open access article)

64. Eisenbeiss L, Binz TM, Baumgartner MR, Kraemer T, Steuer AE (2020) Towards best practice in hair metabolomic studies: systematic investigation on the impact of hair length and color. Metabolites 10:381-393. https://doi.org/10.3390/metabo1010 0381 (open access article)

65. Miolo G, Tucci M, Menilli L, Stocchero G, Vogliardi S, Scrivano S, Montisci M, Favretto D (2018) A study on photostability of amphetamines and ketamine in hair irradiated under artificial sunlight. Brain Sci 8:96. https://doi.org/10.3390/brainsci8060096 (open access article)

66. Wada M, Ikeda R, Kuroda N, Nakashima K (2010) Analytical methods for abused drugs in hair and their applications. Anal Bioanal Chem 397:1039-1067. https://doi.org/10.1007/ s00216-010-3569-z

67. Kintz P (2018) Hair analysis in forensic toxicology: an updated review with a special focus on pitfalls. Curr Pharm Des 23:5480 5486. https://doi.org/10.2174/1381612823666170929155628

68. Kuwayama K, Miyaguchi H, Kanamori T, Tsujikawa K, Yamamuro T, Segawa H, Okada Y, Iwata YT (2021) Development of the "selective concentration" analytical method for drug-containing hair regions based on micro-segmental analysis to identify a trace amount of drug in hair: hair analysis following single-dose ingestion of midazolam. Forensic Toxicol 39:156-166. https:// doi.org/10.1007/s11419-020-00553-8

69. Kernalléguen A, Enjalbal C, Alvarez J-C, Belgacem O, Léonetti G, Lafitte D, Pélissier-Alicot A-L (2018) Synthetic cannabinoid isomers characterization by MALDI-MS ${ }^{3}$ imaging: application to single scalp hair. Anal Chim Acta 1041:87-93. https://doi.org/ 10.1016/j.aca.2018.09.036

70. Kamata T, Shima N, Miki A, Matsuo E, Yamamoto T, Tsuchihashi H, Sato T, Shimma S, Katagi M (2020) High spatialresolution matrix-assisted laser desorption/ionization-ion traptime-of-flight tandem mass spectrometry imaging for depicting longitudinal and transverse distribution of drugs incorporated 
into hair. Anal Chem 92:5821-5829. https://doi.org/10.1021/acs. analchem.9b05401

71. Cuypers E, Flanagan RJ (2018) The interpretation of hair analysis for drugs and drug metabolites. Clin Toxicol 56:90-100. https:// doi.org/10.1080/15563650.2017.1379603

72. Drummer OH, Gerostamoulos D, LeBeau MA, Pragst F (2020) Concerns on the misinterpretation of very low drug concentrations in hair. J Anal Toxicol 44:e6-e8. https://doi.org/10.1093/ jat/bkaa078

73. Vogliardi S, Tucci M, Stocchero G, Ferrara SD, Favretto D (2015) Sample preparation methods for determination of drugs of abuse in hair samples: a review. Anal Chim Acta 857:1-27. https://doi.org/10.1016/j.aca.2014.06.053

74. Kutyshenko VP, Molchanov M, Beskaravayny P, Uversky VN, Timchenko MA (2011) Analyzing and mapping sweat metabolomics by high-resolution NMR spectroscopy. PLoS ONE 6:e28824. https://doi.org/10.1371/journal.pone.0028824 (open access article)

75. Meyer F, Laitano O, Bar-Or O, McDougall D, Heigenhauser GJF (2007) Effect of age and gender on sweat lactate and ammonia concentrations during exercise in the heat. Braz $\mathrm{J}$ Med Biol Res 40:135-143. https://doi.org/10.1590/s0100$879 \times 2006005000044$ (open access article)

76. Jadoon S, Karim S, Akram MR, Khan AK, Zia MA, Siddiqi AR, Murtaza G (2015) Recent developments in sweat analysis and its applications. Int J Anal Chem 2015:164974. https://doi. org/10.1155/2015/164974

77. Hussain JN, Mantri N, Cohen MM (2017) Working up a good sweat - the challenges of standardising sweat collection for metabolomics analysis. Clin Biochem Rev 38:13-34 (PMID: 28798503)

78. De Giovanni N, Fucci N (2013) The Current status of sweat testing for drugs of abuse: a review. Curr Med Chem 20:545561. https://doi.org/10.2174/092986713804910139

79. Kacinko SL, Barnes AJ, Schwilke EW, Cone EJ, Moolchan ET, Huestis MA (2005) Disposition of cocaine and its metabolites in human sweat after controlled cocaine administration. Clin Chem 51:2085-2094. https://doi.org/10.1373/clinchem.2005. 054338 (open access article)

80. Tavares L, Monedeiro F, Bordin DM, De Martinis BS (2020) Investigation of ayahuasca $\beta$-carboline alkaloids and tryptamine in sweat samples from religious community participants by GC-MS. J Anal Toxicol 44:601-609. https://doi. org/10.1093/jat/bkz116

81. Uemura N, Nath RP, Harkey MR, Henderson GL, Mendelson J, Jones RT (2004) Cocaine levels in sweat collection patches vary by location of patch placement and decline over time. J Anal Toxicol 28:253-259. https://doi.org/10.1093/jat/28.4.253 (open access article)

82. Huestis MA, Oyler JM, Cone EJ, Wstadik AT, Schoendorfer D, Joseph RE Jr (1999) Sweat testing for cocaine, codeine and metabolites by gas chromatography-mass spectrometry. J Chromatogr B 733:247-264. https://doi.org/10.1016/s03784347(99)00246-7

83. Penders J, Verstraete A (2006) Laboratory guidelines and standards in clinical and forensic toxicology. Accred Qual Assur 11:284-290. https://doi.org/10.1007/s00769-006-0131-y

84. Badiye A, Kapoor N, Menezes RG (2021) Chain of custody [updated 2021 Feb 21]. In: StatPearls [Internet]. StatPearls Publishing, Treasure Island. https://www.ncbi.nlm.nih.gov/ books/NBK551677/. Accessed 10 Jun 2021

85. Kidwell DA, Smith FP (2001) Susceptibility of PharmChek ${ }^{\mathrm{TM}}$ drugs of abuse patch to environmental contamination. Forensic Sci Int 116:89-106. https://doi.org/10.1016/S0379-0738(00) 00353-4
86. Buono MJ, Ball KD, Kolkhorst FW (2007) Sodium ion concentration vs. sweat rate relationship in humans. J Appl Physiol 103:990-994. https://doi.org/10.1152/japplphysiol.00015.2007 (open access article)

87. Luque de Castro MD (2016) Sweat as a clinical sample: what is done and what should be done. Bioanalysis 8:85-88. https:// doi.org/10.4155/bio.15.229 (open access article)

88. Aberl F, VanDine R (2005) Saliva and sweat testing with Drugwipe ${ }^{\circledR}$. In: Wong RC, Tse HY (eds) Drugs of abuse. Forensic science and medicine. Humana Press, Totowa, pp 161-175. https://doi.org/10.1007/978-1-59259-951-6_10

89. Kang J-S, Lee M-H (2009) Overview of therapeutic drug monitoring. Korean J Intern Med 24:1-10. https://doi.org/10.3904/ kjim.2009.24.1.1 (open access article)

90. Barnes AJ, Smith ML, Kacinko SL, Schwilke EW, Cone EJ, Moolchan ET, Huestis MA (2008) Excretion of methamphetamine and amphetamine in human sweat following controlled oral methamphetamine administration. Clin Chem 54:172-180. https://doi.org/10.1373/clinchem.2007.092304 (open access article)

91. Barnes AJ, De Martinis BS, Gorelick DA, Goodwin RS, Kolbrich EA, Huestis MA (2009) Disposition of MDMA and metabolites in human sweat following controlled MDMA administration. Clin Chem 55:454-462. https://doi.org/10.1373/clinchem.2008. 117093 (open access article)

92. De Martinis BS (2008) Sweat as an alternative matrix for amphetamines and methylenedioxy derivatives analysis. Curr Pharm Anal 4:274-278. https://doi.org/10.2174/1573412087 86306225

93. Liberty HJ, Johnson B, Fortner N, Randolph D (2003) Detecting crack and other cocaine use with fastpatches. Addict Biol 8:191-200. https://doi.org/10.1080/1355621031000117428

94. Huestis MA, Scheidweiler KB, Saito T, Fortner N, Abraham T, Gustafson RA, Smith ML (2008) Excretion of $\Delta^{9}$ tetrahydrocannabinol in sweat. Forensic Sci Int 174:173-177. https://doi.org/10.1016/j.forsciint.2007.04.002

95. Gambelunghe C, Fucci N, Aroni K, Bacci M, Marcelli A, Rossi R (2016) Cannabis use surveillance by sweat analysis. Ther Drug Monit 38:634-639. https://doi.org/10.1097/FTD.0000000000 000327

96. Cone EJ, Hillsgrove MJ, Jenkins AJ, Keenan RM, Darwin WD (1994) Sweat testing for heroin, cocaine, and metabolites. J Anal Toxicol 18:298-305. https://doi.org/10.1093/jat/18.6.298

97. Huestis MA, Cone EJ, Wong CJ, Umbricht A, Preston KL (2000) Monitoring opiate use in substance abuse treatment patients with sweat and urine drug testing. J Anal Toxicol 24:509-521. https:// doi.org/10.1093/jat/24.7.509 (open access article)

98. Clark DA (1977) Times of first void and first stool in 500 newborns. Pediatrics 60:457-459 (PMID: 905009)

99. Metaj M, Laroia N, Lawrence RA, Ryan RM (2003) Comparison of breast- and formula-fed normal newborns in time to first stool and urine. J Perinatol 23:624-628. https://doi.org/10.1038/sj.jp. 7210997 (open access article)

100. Bekkali N, Hamers SL, Schipperus MR, Reitsma JB, Valerio PG, Van Toledo L, Benninga MA (2008) Duration of meconium passage in preterm and term infants. Arch Dis Child Fetal Neonatal Ed 93:F376-F379. https://doi.org/10.1136/adc.2008.138024

101. Jacques SM, Qureshi F (2020) Does in utero meconium passage in term stillbirth correlate with autopsy and placental findings of hypoxia or inflammation?. J Matern Neonatal Med. https://doi. org/10.1080/14767058.2020.1770217 [ahead of print]

102. Gareri J, Klein J, Koren G (2006) Drugs of abuse testing in meconium. Clin Chim Acta 366:101-111. https://doi.org/10.1016/j. cca.2005.10.028

103. Harries JT (1978) Meconium in health and disease. Br Med Bull 34:75-78. https://doi.org/10.1093/oxfordjournals.bmb.a071462 
104. Szeto HH (1993) Kinetics of drug transfer to the fetus. Clin Obstet Gynecol 36:246-254. https://doi.org/10.1097/00003081199306000-00006

105. Diamant NE (1985) Development of esophageal function. Am Rev Respir Dis 131:S29-S32. https://doi.org/10.1164/arrd.1985. 131.S5.S29

106. Koren G, Cohen R (2019) Quantifying fetal alcohol exposure by meconium fatty acid ethyl esters (FAEE); association with adverse fetal outcomes and population estimates of fetal alcohol exposure. Drug Metab Rev 51:524-532. https://doi.org/10.1080/ 03602532.2019.1671859

107. Carlier J, La Maida N, Di Trana A, Huestis MA, Pichini S, Busardò FP (2020) Testing unconventional matrices to monitor for prenatal exposure to heroin, cocaine, amphetamines, synthetic cathinones, and synthetic opioids. Ther Drug Monit 42:205-221. https://doi.org/10.1097/FTD.0000000000000719

108. Concheiro M, Lendoiro E, de Castro A, Gónzalez-Colmenero E, Concheiro-Guisan A, Peñas-Silva P, Macias-Cortiña M, CruzLandeira A, López-Rivadulla M (2017) Bioanalysis for cocaine, opiates, methadone, and amphetamines exposure detection during pregnancy. Drug Test Anal 9:898-904. https://doi.org/10. 1002/dta.2087

109. Wood KE, Krasowski MD, Strathmann FG, McMillin GA (2014) Meconium drug testing in multiple births in the USA. J Anal Toxicol 38:397-403. https://doi.org/10.1093/jat/bku061 (open access article)

110. McMillin GA, Wood KE, Strathmann FG, Krasowski MD (2015) Patterns of drugs and drug metabolites observed in meconium. Ther Drug Monit 37:568-580. https://doi.org/10.1097/FTD. 0000000000000181

111. Bakdash A, Burger P, Goecke TW, Fasching PA, Reulbach U, Bleich S, Hastedt M, Rothe M, Beckmann MW, Pragst F, Kornhuber J (2010) Quantification of fatty acid ethyl esters (FAEE) and ethyl glucuronide $(\mathrm{EtG})$ in meconium from newborns for detection of alcohol abuse in a maternal health evaluation study. Anal Bioanal Chem 396:2469-2477. https://doi.org/10.1007/ s00216-010-3474-5

112. Burd L, Hofer R (2008) Biomarkers for detection of prenatal alcohol exposure: a critical review of fatty acid ethyl esters in meconium. Birth Defects Res Part A Clin Mol Teratol 82:487493. https://doi.org/10.1002/bdra.20464

113. Concheiro M, Huestis MA (2018) Drug exposure during pregnancy: analytical methods and toxicological findings. Bioanalysis 10:587-606. https://doi.org/10.4155/bio-2017-0260

114. Wabuyele SL, Colby JM, McMillin GA (2018) Detection of drug-exposed newborns. Ther Drug Monit 40:166-185. https:// doi.org/10.1097/FTD.0000000000000485

115. Marin SJ, Merrell M, McMillin GA (2011) Drugs of abuse detection in meconium: a comparison between ELISA and biochip microarray. J Anal Toxicol 35:40-45. https://doi.org/10.1093/ anatox/35.1.40 (open access article)

116. Bager H, Christensen LP, Husby S, Bjerregaard L (2017) Biomarkers for the detection of prenatal alcohol exposure: a review. Alcohol Clin Exp Res 41:251-261. https://doi.org/10.1111/acer. 13309

117. Chan D, Bar-Oz B, Pellerin B, Paciorek C, Klein J, Kapur B, Farine D, Koren G (2003) Population baseline of meconium fatty acid ethyl esters among infants of nondrinking women in Jerusalem and Toronto. Ther Drug Monit 25:271-278. https://doi.org/ 10.1097/00007691-200306000-00004

118. Joya X, Marchei E, Salat-Batlle J, García-Algar O, Calvaresi V, Pacifici R, Pichini S (2016) Fetal exposure to ethanol: relationship between ethyl glucuronide in maternal hair during pregnancy and ethyl glucuronide in neonatal meconium. Clin Chem Lab Med 54:427-435. https://doi.org/10.1515/cclm-2015-0516
119. Himes SK, Dukes KA, Tripp T, Petersen JM, Raffo C, Burd L, Odendaal H, Elliott AJ, Hereld D, Signore C, Willinger M, Huestis MA (2015) Clinical sensitivity and specificity of meconium fatty acid ethyl ester, ethyl glucuronide, and ethyl sulfate for detecting maternal drinking during pregnancy. Clin Chem 61:523-532. https://doi.org/10.1373/clinchem.2014.233718 (open access article)

120. López-Rabuñal Á, Lendoiro E, Concheiro M, López-Rivadulla M, Cruz A, De-Castro-Ríos A (2019) A LC-MS/MS method for the determination of common synthetic cathinones in meconium. J Chromatogr B 1124:349-355. https://doi.org/10.1016/j.jchro mb.2019.06.030

121. Pichini S, Rotolo MC, García J, Girona N, Leal L, García-Algar O, Pacifici R (2014) Neonatal withdrawal syndrome after chronic maternal consumption of 4-methylethcathinone. Forensic Sci Int 245:e33-e35. https://doi.org/10.1016/j.forsciint.2014.10.027

122. Nemeškalová A, Bursová M, Sýkora D, Kuchař M, Čabala R, Hložek T (2019) Salting out assisted liquid-liquid extraction for liquid chromatography tandem-mass spectrometry determination of amphetamine-like stimulants in meconium. J Pharm Biomed Anal 172:42-49. https://doi.org/10.1016/j.jpba.2019.04.036

123. Wu F, Marin SJ, McMillin GA (2017) Stability of 21 cocaine, opioid and benzodiazepine drug analytes in spiked meconium at three temperatures. J Anal Toxicol 41:196-204. https://doi.org/ 10.1093/jat/bkw113 (open access article)

124. Zelner I, Hutson JR, Kapur BM, Feig DS, Koren G (2012) Falsepositive meconium test results for fatty acid ethyl esters secondary to delayed sample collection. Alcohol Clin Exp Res 36:14971506. https://doi.org/10.1111/j.1530-0277.2012.01763.x

125. Walker A (2010) Breast milk as the gold standard for protective nutrients. J Pediatr 156:S3-S7. https://doi.org/10.1016/j.jpeds. 2009.11.021

126. Ballard O, Morrow AL (2013) Human milk composition: nutrients and bioactive factors. Pediatr Clin North Am 60:49-74. https://doi.org/10.1016/j.pcl.2012.10.002 (open access article)

127. Ryan SA, Ammerman SD, O'Connor ME, Committee on substance use and prevention and section on breastfeeding (2018) Marijuana use during pregnancy and breastfeeding: implications for neonatal and childhood outcomes. Pediatrics 142:e20181889. https://doi.org/10.1542/peds.2018-1889

128. Vahidinia A, Samiee F, Faradmal J, Rahmani A, Javad MT, Leili M (2019) Mercury, lead, cadmium, and barium levels in human breast milk and factors affecting their concentrations in Hamadan. Iran Biol Trace Elem Res 187:32-40. https://doi.org/10. 1007/s12011-018-1355-5

129. Johnson-Restrepo B, Addink R, Wong C, Arcaro K, Kannan K (2007) Polybrominated diphenyl ethers and organochlorine pesticides in human breast milk from Massachusetts, USA. J Environ Monit 9:1205-1212. https://doi.org/10.1039/B711409P

130. Rowe H, Baker T, Hale TW (2013) Maternal medication, drug use, and breastfeeding. Pediatr Clin North Am 60:275-294. https://doi.org/10.1016/j.pcl.2012.10.009

131. Pichini S, Altieri I, Zuccaro P, Pacifici R (1996) Drug monitoring in nonconventional biological fluids and matrices. Clin Pharmacokinet 30:211-228. https://doi.org/10.2165/00003088-19963 0030-00003

132. Escuder-Vieco D, Garcia-Algar Ó, Joya X, Marchei E, Pichini S, Pacifici R, Pallás-Alonso CR (2016) Breast milk and hair testing to detect illegal drugs, nicotine, and caffeine in donors to a human milk bank. J Hum Lact 32:542-545. https://doi.org/10. 1177/0890334416648110

133. Fríguls B, Joya X, García-Algar O, Pallás CR, Vall O, Pichini S (2010) A comprehensive review of assay methods to determine drugs in breast milk and the safety of breastfeeding when taking drugs. Anal Bioanal Chem 397:1157-1179. https://doi.org/10. 1007/s00216-010-3681-0 
134. Bessa MA, Mitsuhiro SS, Chalem E, Barros MM, Guinsburg R, Laranjeira R (2010) Underreporting of use of cocaine and marijuana during the third trimester of gestation among pregnant adolescents. Addict Behav 35:266-269. https://doi.org/10.1016/j. addbeh.2009.10.007

135. Esteban M, Castaño A (2009) Non-invasive matrices in human biomonitoring: a review. Environ Int 35:438-449. https://doi.org/ 10.1016/j.envint.2008.09.003

136. de Oliveira Silveira G, Pego AMF, Pereira e Silva J, Yonamine M (2019) Green sample preparations for the bioanalysis of drugs of abuse in complex matrices. Bioanalysis 11:295-312. https:// doi.org/10.4155/bio-2018-0208

137. Ramos Santos WJJr, De Martinis BS (2020) Psychoactive substances in human breast milk: a review of analytical strategies for their investigation. Bioanalysis 12:1263-1274. https://doi.org/10. 4155/bio-2020-0155

138. Behpour M, Nojavan S, Asadi S, Shokri A (2020) Combination of gel-electromembrane extraction with switchable hydrophilicity solvent-based homogeneous liquid-liquid microextraction followed by gas chromatography for the extraction and determination of antidepressants in human serum, breast milk and wastewater. J Chromatogr A 1621:461041. https://doi.org/10. 1016/j.chroma.2020.461041

139. Sempio C, Wymore E, Palmer C, Bunik M, Henthorn TK, Christians U, Klawitter J (2020) Detection of cannabinoids by LCMS-MS and ELISA in breast milk. J Anal Toxicol. https://doi. org/10.1093/jat/bkaa142 [ahead of print]

140. D'Apolito K (2013) Breastfeeding and substance abuse. Clin Obstet Gynecol 56:202-211. https://doi.org/10.1097/GRF.0b013 e31827e6b71

141. Hale TW, Rowe HE (2017) Medications and mothers' milk. Springer Publishing Co, New York

142. Bertrand KA, Hanan NJ, Honerkamp-Smith G, Best BM, Chambers CD (2018) Marijuana use by breastfeeding mothers and cannabinoid concentrations in breast milk. Pediatrics 142:e20181076. https://doi.org/10.1542/peds.2018-1076 (open access article)

143. Tennes K, Avitable N, Blackard C, Boyles C, Hassoun B, Holmes L, Kreye M (1985) Marijuana: prenatal and postnatal exposure in the human. NIDA Res Monogr 59:48-60 (PMID: 3929132)

144. Astley SJ, Little RE (1990) Maternal marijuana use during lactation and infant development at one year. Neurotoxicol Teratol 12:161-168. https://doi.org/10.1016/0892-0362(90)90129-Z

145. Chasnoff IJ, Lewis DE, Squires L (1987) Cocaine intoxication in a breast-fed infant. Pediatrics 80:836-838 (PMID: 3684393)

146. Abdel-Latif ME, Pinner J, Clews S, Cooke F, Lui K, Oei J (2006) Effects of breast milk on the severity and outcome of neonatal abstinence syndrome among infants of drug-dependent mothers. Pediatrics 117:e1163-e1169. https://doi.org/10.1542/peds. 2005-1561

147. National Library of Medicine (USA) (2006) Drugs and lactation database (LactMed) [Internet]. https://www.ncbi.nlm.nih. gov/books/NBK501922/. Accessed 4 Jun 2021

148. Ventrella D, Forni M, Bacci ML, Annaert P (2019) Non-clinical models to determine drug passage into human breast milk. Curr Pharm Des 25:534-548. https://doi.org/10.2174/1381612825 666190320165904

149. Pigaiani N, Bertaso A, De Palo EF, Bortolotti F, Tagliaro F (2020) Vitreous humor endogenous compounds analysis for post-mortem forensic investigation. Forensic Sci Int 310:110235. https://doi.org/10.1016/j.forsciint.2020.110235

150. Kugelberg FC, Jones AW (2007) Interpreting results of ethanol analysis in postmortem specimens: a review of the literature. Forensic Sci Int 165:10-29. https://doi.org/10.1016/j.forsciint. 2006.05.004
151. Wójtowicz A, Wietecha-Posłuszny R, Snamina M (2020) Contemporary trends in drug analysis of vitreous humor: a critical review. Trends Analyt Chem 129:115935. https://doi.org/10. 1016/j.trac.2020.115935

152. Logan BK, Stafford DT (1989) Direct analysis of anticonvulsant drugs in vitreous humour by HPLC using a column switching technique. Forensic Sci Int 41:125-134. https://doi.org/10.1016/ 0379-0738(89)90244-2

153. Bévalot F, Cartiser N, Bottinelli C, Fanton L, Guitton J (2016) Vitreous humor analysis for the detection of xenobiotics in forensic toxicology: a review. Forensic Toxicol 34:12-40. https://doi. org/10.1007/s11419-015-0294-5 (open access article)

154. Cox D, Phipps RAJ, Levine B, Jacobs A, Fowler D (2007) Distribution of phencyclidine into vitreous humor. J Anal Toxicol 31:537-539. https://doi.org/10.1093/jat/31.8.537 (open access article)

155. Fernández $\mathrm{P}$, Seoane $\mathrm{S}$, Vázquez $\mathrm{C}$, Tabernero MJ, Carro AM, Lorenzo RA (2013) Chromatographic determination of drugs of abuse in vitreous humor using solid-phase extraction. J Appl Toxicol 33:740-745. https://doi.org/10.1002/jat.2722

156. Metushi IG, Fitzgerald RL, McIntyre IM (2016) Assessment and comparison of vitreous humor as an alternative matrix for forensic toxicology screening by GC-MS. J Anal Toxicol 40:243-247. https://doi.org/10.1093/jat/bkw009 (open access article)

157. Harper DR (1989) A comparative study of the microbiological contamination of postmortem blood and vitreous humour samples taken for ethanol determination. Forensic Sci Int 43:37-44. https://doi.org/10.1016/0379-0738(89)90120-5

158. Madea B (2005) Is there recent progress in the estimation of the postmortem interval by means of thanatochemistry? Forensic Sci Int 151:139-149. https://doi.org/10.1016/j.forsciint.2005.01.013

159. Savini F, Tartaglia A, Coccia L, Palestini D, D’ Ovidio C, de Grazia U, Merone GM, Bassotti E, Locatelli M (2020) Ethanol determination in post-mortem samples: correlation between blood and vitreous humor concentration. Molecules 25:2724. https://doi. org/10.3390/molecules25122724 (open access article)

160. Rees KA, Jones NS, McLaughlin PA, Osselton MD (2012) The effect of sodium fluoride preservative and storage temperature on the stability of 6-acetylmorphine in horse blood, sheep vitreous and deer muscle. Forensic Sci Int 217:189-195. https://doi.org/ 10.1016/j.forsciint.2011.11.002

161. Forrest ARW (1993) Obtaining samples at post mortem examination for toxicological and biochemical analyses. J Clin Pathol 46:292-296. https://doi.org/10.1136/jcp.46.4.292 (open access article)

162. Fernández P, Rodríguez P, Bermejo AM, López-Rivadulla M, Cruz A (1994) Simultaneous determination of cocaine and benzoylecgonine in vitreous humor by HPLC. J Liq Chromatogr 17:883-890. https://doi.org/10.1080/10826079408013375

163. Margalho C, Castanheira A, Real FC, Gallardo E, López-Rivadulla M (2016) Determination of "new psychoactive substances" in postmortem matrices using microwave derivatization and gas chromatography-mass spectrometry. J Chromatogr B 1020:1423. https://doi.org/10.1016/j.jchromb.2016.03.001

164. Peres MD, Pelição FS, Caleffi B, De Martinis BS (2014) Simultaneous quantification of cocaine, amphetamines, opiates and cannabinoids in vitreous humor. J Anal Toxicol 38:39-45. https:// doi.org/10.1093/jat/bkt093 (open access article)

165. Pelander A, Ristimaa J, Ojanperä I (2010) Vitreous humor as an alternative matrix for comprehensive drug screening in postmortem toxicology by liquid chromatography-time-of-flight mass spectrometry. J Anal Toxicol 34:312-318. https://doi.org/ 10.1093/jat/34.6.312 (open access article)

166. Fernández P, Aldonza M, Bouzas A, Lema M, Bermejo AM, Tabernero MJ (2006) GC-FID determination of cocaine and its 
metabolites in human bile and vitreous humor. J Appl Toxicol 26:253-257. https://doi.org/10.1002/jat.1130

167. Wyman J, Bultman S (2004) Postmortem distribution of heroin metabolites in femoral blood, liver, cerebrospinal fluid, and vitreous humor. J Anal Toxicol 28:260-263. https://doi.org/10.1093/ jat/28.4.260 (open access article)

168. Sanches LR, Seulin SC, Leyton V, Paranhos BAPB, Pasqualucci CA, Muñaoz DR, Osselton MD, Yonamine M (2012) Determination of opiates in whole blood and vitreous humor: a study of the matrix effect and an experimental design to optimize conditions for the enzymatic hydrolysis of glucuronides. J Anal Toxicol 36:162-170. https://doi.org/10.1093/jat/bks007 (open access article)

169. Ishikawa AA, Bordin DM, de Campos EG, Blanes L, Doble P, De Martinis BS (2018) A gas chromatography-mass spectrometry method for toxicological analysis of MDA, MDEA and MDMA in vitreous humor samples from victims of car accidents. J Anal Toxicol 42:661-666. https://doi.org/10.1093/jat/bky044 (open access article)

170. Jenkins AJ, Oblock J (2008) Phencyclidine and cannabinoids in vitreous humor. Leg Med 10:201-203. https://doi.org/10.1016/j. legalmed.2008.01.002

171. Bazmi E, Behnoush B, Akhgari M, Bahmanabadi L (2016) Quantitative analysis of benzodiazepines in vitreous humor by high-performance liquid chromatography. SAGE Open Med 4:2050312116666243. https://doi.org/10.1177/2050312116 666243 (open access article)

172. Costa JL, Morrone AR, Resende RR, da Matta Chasin AA, Tavares MFM (2014) Development of a method for the analysis of drugs of abuse in vitreous humor by capillary electrophoresis with diode array detection (CE-DAD). J Chromatogr B 945-946:84-91. https://doi.org/10.1016/j.jchromb.2013.10.014

173. Iskierka M, Zawadzki M, Szpot P, Jurek T (2021) Detection of drugs in postmortem specimens of blood, vitreous humor and bone marrow aspirate. J Anal Toxicol 45:348-355. https://doi. org/10.1093/jat/bkaa083

174. Clauwaert KM, Van Bocxlaer JF, De Letter EA, Van Calenbergh S, Lambert WE, De Leenheer AP (2000) Determination of the designer drugs 3,4-methylenedioxymethamphetamine, 3,4-methylenedioxyethylamphetamine, and 3,4-methylenedioxyamphetamine with HPLC and fluorescence detection in whole blood, serum, vitreous humor, and urine. Clin Chem 46:1968-1977. https://doi.org/10.1093/clinchem/46.12.1968 (open access article)

175. Favretto D, Frison G, Maietti S, Ferrara SD (2007) LC-ESI-MS/ MS on an ion trap for the determination of LSD, iso-LSD, norLSD and 2-oxo-3-hydroxy-LSD in blood, urine and vitreous humor. Int J Legal Med 121:259-265. https://doi.org/10.1007/ s00414-006-0078-x

176. Fernández P, Seoane S, Vázquez C, Bermejo AM, Carro AM, Lorenzo RA (2011) A rapid analytical method based on microwave-assisted extraction for the determination of drugs of abuse in vitreous humor. Anal Bioanal Chem 401:2177-2186. https:// doi.org/10.1007/s00216-011-5279-6

177. Kovatsi L, Rentifis K, Giannakis D, Njau S, Samanidou V (2011) Disposable pipette extraction for gas chromatographic determination of codeine, morphine, and 6-monoacetylmorphine in vitreous humor. J Sep Sci 34:1716-1721. https://doi.org/10.1002/jssc. 201100124

178. Scott KS, Oliver JS (1999) Vitreous humor as an alternative sample to blood for the supercritical fluid extraction of morphine and 6-monoacetylmorphine. Med Sci Law 39:77-81. https://doi.org/ $10.1177 / 002580249903900114$

179. Badakhshan D, Ramezani M (2020) Evaluation and determination of tramadol and methadone in vitreous samples with the aid of dispersive liquid-liquid microextraction-high performance liquid chromatography. J Chil Chem Soc 65:4722-4725. https:// doi.org/10.4067/S0717-97072020000104722

180. dos Santos MF, Yamada A, Seulin SC, Leyton V, Pasqualucci CAG, Muñoz DR, Yonamine M (2016) Liquid-phase microextraction and gas chromatographic-mass spectrometric analysis of antidepressants in vitreous humor: study of matrix effect of human and bovine vitreous and saline solution. J Anal Toxicol 40:187-193. https://doi.org/10.1093/jat/bkv141 (open access article)

181. Mackey-Bojack S, Kloss J, Apple F (2000) Cocaine, cocaine metabolite, and ethanol concentrations in postmortem blood and vitreous humor. J Anal Toxicol 24:59-65. https://doi.org/ 10.1093/jat/24.1.59 (open access article)

182. Pragst F, Spiegel K, Leuschner U, Hager A (1999) Detection of 6-acetylmorphine in vitreous humor and cerebrospinal fluidcomparison with urinary analysis for proving heroin administration in opiate fatalities. J Anal Toxicol 23:168-172. https://doi. org/10.1093/jat/23.3.168 (open access article)

183. Rees KA, Jones NS, McLaughlin PA, Seulin S, Leyton V, Yonamine M, Osselton MD (2012) The effect of sodium fluoride preservative and storage temperature on the stability of cocaine in horse blood, sheep vitreous and deer muscle. Forensic Sci Int 217:182-188. https://doi.org/10.1016/j.forsciint.2011.11.001

184. Cabarcos P, Tabernero MJ, Álvarez I, López P, Fernández P, Bermejo AM (2010) Analysis of six benzodiazepines in vitreous humor by high-performance liquid chromatography-photodiodearray detection. J Anal Toxicol 34:539-542. https://doi.org/10. 1093/jat/34.9.539 (open access article)

185. Thaulow CH, Øiestad ÅML, Rogde S, Karinen R, Brochmann GW, Andersen JM, Høiseth G, Handal M, Mørland J, Arnestad M, Øiestad EL, Strand DH, Vindenes V (2018) Metabolites of heroin in several different post-mortem matrices. J Anal Toxicol 42:311-320. https://doi.org/10.1093/jat/bky002 (open access article)

186. McLaughlin P, Maskell PD, Pounder D, Osselton D (2019) Use of the randox evidence investigator immunoassay system for near-body drug screening during post-mortem examination in 261 forensic cases. Forensic Sci Int 294:211-215. https://doi. org/10.1016/j.forsciint.2018.11.018

187. Fucci N, De Giovanni N, De Giorgio F, Liddi R, Chiarotti M (2006) An evaluation of the Cozart ${ }^{\circledR}$ RapiScan system as an on-site screening tool for drugs of abuse in a non-conventional biological matrix: vitreous humor. Forensic Sci Int 156:102-105. https://doi.org/10.1016/j.forsciint.2004.12.023

188. Chronister CW, Walrath JC, Goldberger BA (2001) Rapid detection of benzoylecgonine in vitreous humor by enzyme immunoassay. J Anal Toxicol 25:621-624. https://doi.org/10.1093/jat/ 25.7.621 (open access article)

189. Chronister CW, Gund AL, Goldberger BA (2008) Rapid detection of opioids in vitreous humor by enzyme immunoassay. $\mathrm{J}$ Anal Toxicol 32:601-604. https://doi.org/10.1093/jat/32.8.601 (open access article)

190. Gevorkyan J, Kinyua J, Pearring S, Rodda LN (2021) A case series of etizolam in opioid-related deaths. J Anal Toxicol. https://doi.org/10.1093/jat/bkaa146 [ahead of print]

191. Logan BK, Stafford DT (1990) High-performance liquid chromatography with column switching for the determination of cocaine and benzoylecgonine concentrations in vitreous humor. J Forensic Sci 35:1303-1309 (PMID: 2262767)

192. Alvear E, von Baer D, Mardones C, Hitschfeld A (2014) Determination of cocaine and its major metabolite benzoylecgonine in several matrices obtained from deceased individuals with presumed drug consumption prior to death. J Forensic Leg Med 23:37-43. https://doi.org/10.1016/j.jflm.2014.01.003 
193. Mazarr-Proo S, Kerrigan S (2005) Distribution of GHB in tissues and fluids following a fatal overdose. J Anal Toxicol 29:398-400. https://doi.org/10.1093/jat/29.5.398 (open access article)

194. Ntoupa PSA, Armaos KP, Athanaselis SA, Spiliopoulou CA, Papoutsis II (2020) Study of the distribution of antidepressant drugs in vitreous humor using a validated GC/MS method. Forensic Sci Int 317:110547. https://doi.org/10.1016/j.forsciint. 2020.110547

195. Øiestad ÅML, Karinen R, Rogde S, Nilsen S, Eldor K-BB, Brochmann G-W, Arnestad M, Øiestad EL, Peres MD, Kristoffersen L, Vindenes V (2018) Comparative study of postmortem concentrations of antidepressants in several different matrices. J Anal Toxicol 42:446-458. https://doi.org/10.1093/jat/bky030 (open access article)

196. Hubbard JA, Navarrete AL, Fitzgerald RL, McIntyre IM (2021) Acidic drug concentrations in postmortem vitreous humor and peripheral blood. J Anal Toxicol 45:69-75. https://doi.org/10. 1093/jat/bkz076

197. Saenz SR, Lewis RJ, Angier MK, Wagner JR (2017) Postmortem fluid and tissue concentrations of THC, 11-OH-THC and THCCOOH. J Anal Toxicol 41:508-516. https://doi.org/10.1093/jat/ bkx033 (open access article)

198. Lin D-L, Lin R-L (2005) Distribution of 11-nor-9-carboxy$\Delta^{9}$-tetrahydrocannabinol in traffic fatality cases. J Anal Toxicol 29:58-61. https://doi.org/10.1093/jat/29.1.58 (open access article)

199. Gronewold A, Skopp G (2011) A preliminary investigation on the distribution of cannabinoids in man. Forensic Sci Int 210:e7-e11. https://doi.org/10.1016/j.forsciint.2011.04.010

200. Matey JM, García-Ruíz C, Montalvo G, Gómez-Soro JC, Gutierrez-Delicado D, Rodríguez-Gallardo J, Martínez MA (2020) Ultraviolet-visible and high-resolution mass spectrometry for the identification of cyclopropyl-fentanyl in the first fatal case in Spain. J Anal Toxicol 44:927-935. https://doi.org/10.1093/jat/ bkaa081

201. Chesser R, Pardi J, Concheiro M, Cooper G (2019) Distribution of synthetic opioids in postmortem blood, vitreous humor and brain. Forensic Sci Int 305:109999. https://doi.org/10.1016/j. forsciint.2019.109999

202. Fels H, Lottner-Nau S, Sax T, Roider G, Graw M, Auwärter V, Musshoff F (2019) Postmortem concentrations of the synthetic opioid U-47700 in 26 fatalities associated with the drug. Forensic Sci Int 301:e20-e28. https://doi.org/10.1016/j.forsciint.2019.04. 010

203. Martucci HFH, Ingle EA, Hunter MD, Rodda LN (2018) Distribution of furanyl fentanyl and 4-ANPP in an accidental acute death: a case report. Forensic Sci Int 283:e13-e17. https://doi. org/10.1016/j.forsciint.2017.12.005

204. Fels H, Krueger J, Sachs H, Musshoff F, Graw M, Roider G, Stoever A (2017) Two fatalities associated with synthetic opioids: AH-7921 and MT-45. Forensic Sci Int 277:e30-e35. https://doi. org/10.1016/j.forsciint.2017.04.003

205. Sofalvi S, Schueler HE, Lavins ES, Kaspar CK, Brooker IT, Mazzola CD, Dolinak D, Gilson TP, Perch S (2017) An LC-MS-MS method for the analysis of carfentanil, 3-methylfentanyl, 2-furanyl fentanyl, acetyl fentanyl, fentanyl and norfentanyl in postmortem and impaired-driving cases. J Anal Toxicol 41:473-483. https://doi.org/10.1093/jat/bkx052 (open access article)

206. Poklis J, Poklis A, Wolf C, Hathaway C, Arbefeville E, Chrostowski L, Devers K, Hair L, Mainland M, Merves M, Pearson J (2016) Two fatal intoxications involving butyryl fentanyl. J Anal Toxicol 40:703-708. https://doi.org/10.1093/jat/bkw048 (open access article)

207. McIntyre IM, Trochta A, Gary RD, Malamatos M, Lucas JR (2015) An acute acetyl fentanyl fatality: a case report with postmortem concentrations. J Anal Toxicol 39:490-494. https:// doi.org/10.1093/jat/bkv043 (open access article)

208. Margasińska-Olejak J, Celiński R, Fischer A, Stojko J (2019) A fatal case of poisoning of a 19-year-old after taking 3-MMC. Forensic Sci Int 300:e34-e37. https://doi.org/10.1016/j.forsciint. 2019.02.040

209. McIntyre IM, Hamm CE, Sherrard JL, Gary RD, Burton CG, Mena O (2015) Acute 3,4-methylenedioxy- $N$-ethylcathinone (ethylone) intoxication and related fatality: a case report with postmortem concentrations. J Anal Toxicol 39:225-228. https:// doi.org/10.1093/jat/bku146 (open access article)

210. McIntyre IM, Hamm CE, Aldridge L, Nelson CL (2013) Acute methylone intoxication in an accidental drowning-a case report. Forensic Sci Int 231:e1-e3. https://doi.org/10.1016/j.forsciint. 2013.06.005

211. Nowak K, Szpot P, Zawadzki M (2020) The stability of 4-chloromethcathinone in blood and vitreous humor. J Forensic Sci 65:1784-1790. https://doi.org/10.1111/1556-4029.14454

212. Krotulski AJ, Mohr ALA, Papsun DM, Logan BK (2018) Dibutylone (bk-DMBDB): intoxications, quantitative confirmations and metabolism in authentic biological specimens. J Anal Toxicol 42:437-445. https://doi.org/10.1093/jat/bky022

213. Seetohul LN, Pounder DJ (2013) Four fatalities involving 5-IT. J Anal Toxicol 37:447-451. https://doi.org/10.1093/jat/bkt053 (open access article)

214. Andreasen MF, Telving R, Rosendal I, Eg MB, Hasselstrøm JB, Andersen LV (2015) A fatal poisoning involving 25C-NBOMe. Forensic Sci Int 251:e1-e8. https://doi.org/10.1016/j.forsciint. 2015.03.012

215. Andreasen MF, Telving R, Birkler RID, Schumacher B, Johannsen M (2009) A fatal poisoning involving bromo-dragonfly. Forensic Sci Int 183:91-96. https://doi.org/10.1016/j.forsc iint.2008.11.001

216. Poklis JL, Devers KG, Arbefeville EF, Pearson JM, Houston E, Poklis A (2014) Postmortem detection of 25I-NBOMe [2-(4-iodo-2,5-dimethoxyphenyl)-N-[(2-methoxyphenyl)methyl] ethanamine] in fluids and tissues determined by high performance liquid chromatography with tandem mass spectrometry from a traumatic death. Forensic Sci Int 234:e14-e20. https://doi. org/10.1016/j.forsciint.2013.10.015

217. Solimini R, Minutillo A, Kyriakou C, Pichini S, Pacifici R, Busardo FP (2018) Nails in forensic toxicology: an update. Curr Pharm Des 23:5468-5479. https://doi.org/10.2174/1381612823 666170704123126

218. Cartiser N, Bévalot F, Fanton L, Gaillard Y, Guitton J (2011) State-of-the-art of bone marrow analysis in forensic toxicology: a review. Int J Legal Med 125:181-198. https://doi.org/10.1007/ s00414-010-0525-6

219. Concheiro-Guisan A, Concheiro M (2014) Bioanalysis during pregnancy: recent advances and novel sampling strategies. Bioanalysis 6:3133-3153. https://doi.org/10.4155/bio.14.278

220. Ottaviani G, Cameriere R, Cippitelli M, Froldi R, Tassoni G, Zampi M, Cingolani M (2017) Determination of drugs of abuse in a single sample of human teeth by a gas chromatography-mass spectrometry method. J Anal Toxicol 41:32-36. https://doi.org/ 10.1093/jat/bkw105 (open access article)

221. Klima M, Altenburger MJ, Kempf J, Auwärter V, Neukamm MA (2016) Determination of medicinal and illicit drugs in post mortem dental hard tissues and comparison with analytical results for body fluids and hair samples. Forensic Sci Int 265:166-171. https://doi.org/10.1016/j.forsciint.2016.02.021

222. Meier SI, Koelzer SC, Schubert-Zsilavecz M, Toennes SW (2017) Analysis of drugs of abuse in cerumen-correlation of postmortem analysis results with those for blood, urine and hair. Drug Test Anal 9:1572-1585. https://doi.org/10.1002/dta.2177 
223. Shokry E, Marques JG, Ragazzo PC, Pereira NZ, Filho NRA (2017) Earwax as an alternative specimen for forensic analysis. Forensic Toxicol 35:348-358. https://doi.org/10.1007/ s11419-017-0363-z

224. Petrochilou E, Athanaselis S, Nikolaou P, Papadodima S, Panderi I, Spiliopoulou C, Papoutsis I (2019) Synovial fluid as an alternative specimen for quantification of drugs of abuse by GC-MS. Forensic Toxicol 37:496-503. https://doi.org/10.1007/ s11419-019-00465-2

225. Organization of Scientific Area Committees for Forensic Sciences (OSAC) (2021) OSAC research and development needs
- alternative matrices. https://www.nist.gov/osac/osac-researchand-development-needs. Accessed 4 Jun 2021

Publisher's Note Springer Nature remains neutral with regard to jurisdictional claims in published maps and institutional affiliations. 